[VOL. XXVIII, NO. 2

\title{
JUDICIAL NULLIFICATION OF STATUTES UNDER THE CHARTER OF RIGHTS AND FREEDOMS, 1982-1988*
}

\author{
F.L. MORTON, G. SOLOMON, I. MCNISH AND D.W. POULTON**
}

This study assesses the effect of the Charter of Rights on legislative policy-making. Unlike earlier studies limited to the Charter decisions of the Supreme Court of Canada, this study identifies and analyzes all reported federal and provincial Court of appeal decisions from 1982 through 1988 in which a statute was declared invalid, in whole or in part. The authors discuss which Charter rights result in the most "nullifications" of statutes, and judicial activism under the Charter, using a statistical analysis to support their assertions. The study also finds that the Charter has had a greater substantive effect on provincial jurisdiction, than on federal jurisdiction, creating a tension between provincial rights and minority rights which can be moderated or exacerbated by different modes of judicial interpretation.
Cette érude évalue l'effet de la Charte des droits et libertés sur les décisions législatives. A la différence des études précédentes qui se limitaient aux décisions de la Cour suprême du Canada relatives à la Charte, cette étude indique et analyse toutes les décisions rapportées des cours d'appel fédérales et provinciales, de 1982 d 1988, par lesquelles une loi a été abrogée, en totalité ou en partie. Analyse statistique d l'appui, les auteurs relèvent quels sont les droits et libertés de la Charte qui entrainent le plus grand nombre d'annulations et parlent de l'activisme judiciaire auquel la Charte donne lieu. Ils montrent également que la Charte a eu des conséquences de fond plus prononcées au niveau provincial que pour l'administration fédérale, créant ainsi, entre les droits des provinces et ceux des minorités, une tension que peuvent tempérer ou exacerber les divers modes d'interprétation judiciaire.

TABLE OF CONTENTS

I. INTRODUCTION $\ldots \ldots \ldots \ldots \ldots \ldots \ldots \ldots \ldots \ldots \ldots \ldots \ldots$

II. THE CASES $\ldots \ldots \ldots \ldots \ldots \ldots \ldots \ldots \ldots \ldots \ldots \ldots \ldots \ldots \ldots$

III. WHICH CHARTER RIGHTS ARE RESPONSIBLE FOR

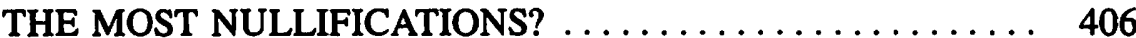

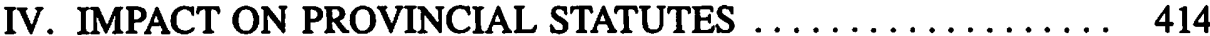

V. ARE JUDGES BECOMING MORE ACTIVIST? . . . . . . 418

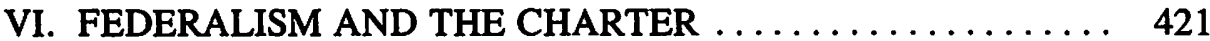

VII. CONCLUSION ......................... 425

\section{INTRODUCTION}

The adoption of the Canadian Charter of Rights and Freedoms' in 1982 marked an important turning point in Canadian constitutional development. The Charter has modified the tradition of parliamentary supremacy with that of con-

* The research reported in this paper was made possible by a four year grant from the Social Sciences and Humanities Research Council of Canada.

** F.L. Morton is an Associate Professor of Political Science and Co-Director of the Research Unit for Socio-Legal Studies at the University of Calgary.

Glenn Solomon studied Political Science at the University of Calgary, and is a third year law student at the University of Alberta. He is Co-Editor-in-Chief of the Alberta Law Review. He will article with the Alberta Court of Appeal in 1990-91.

Ian McNish did his B.A. in Political Science at the University of Calgary; M.A. in Politics at Brock University; and is a third year law student at Queen's University. He will article with the Alberta Court of Appeal in 1990-91.

David Poulton did his B.A. and M.A. in Political Science at the University of Calgary; LL.B. at Dalhousie University; and currently works with the law firm Code Hunter in Calgary.

1. Constitution Act, 1982; Enacted by the Canada Act, 1982 (U.K.), c.11; schedule B. 
stitutional supremacy. In so doing, it also places new restrictions on the legislative autonomy of the provinces in their traditional spheres of jurisdiction. Political opposition to the Charter during its formative stages was based primarily on these issues. Opponents, such as Premier Lyon of Manitoba, claimed that the Charter would replace Parliamentary supremacy with "judicial supremacy", contrary to the tradition of "responsible government" and the democratic norm of majority rule.

Other provincial premiers, such as Blakeney of Saskatchewan and Levesque of Quebec, argued that the judicial interpretation and enforcement of Charter rights would erode the political autonomy of the provinces. Laws clearly within provincial jurisdiction under s.92 of the Constitution Act, 1867 could now be declared invalid by judges because of alleged violations of the Charter. The last minute adoption of the section 33 "legislative override" provision, and Quebec's refusal to sign the Constitution Act, 1982, reflected provincial fear of the potential centralizing influence of the Charter. ${ }^{2}$

Concern with these issues did not end with the adoption of the Charter. The challenge of reconciling the Charter with legislative supremacy has been addressed by several commentators, ${ }^{3}$ as has the "nation building" potential of the Charter. Most such studies have been of an analytical or speculative nature. ${ }^{5}$

There has been only one study that has tried to measure empirically the impact of Charter litigation since 1982 on the actual law-making function of the federal and provincial legislatures. ${ }^{6}$ It suggests that earlier fears of "government by judiciary" under the Charter have been exaggerated. It found that most Charter litigation has not involved legislative-judicial confrontation over statutes and substantive policy issues. Over two-thirds of all reported Charter cases have been challenges to the conduct of government officials (mostly the police) charged with the enforcement of statutes, not against statutes. In those cases that have directly challenged statutes, the judges have been more deferential to legislative judgement. These cases have been less successful (a $28 \%$ success rate) than challenges to the conduct of policemen and others acting in an executive-administrative capacity (33\% success rate). As for a possible centralizing effect of the Charter, the results were mixed. More federal statutes than provincial statutes had been declared null in Charter cases, but the "success ratio" was higher against provincial statutes (30\% compared to $23 \%$ ). ${ }^{7}$

2. See Roy Romanow, John Whyte, and Howard Leeson, Canada Notwithstanding: The Making of the Constitution 1976-1982 (Toronto: Carswell, 1984), Ch. 8.

3. See Jennifer Smith, "The Origins of Judicial Review in Canada" (1983) 16 Canadian Joumal of Political Science 115. Also see Patrick Monahan, Politics and the Constitution: The Charter, Federalism and The Supreme Court of Canada. (Toronto: Carswell-Methuen, 1987).

4. See Rainer Knopff and F.L. Morton, "Nation-Building and the Charter of Rights and Freedoms", in Alan Caims and C. Williams, eds. Constitutionalism, Citizenship, and Society in Canada (Toronto: University of Toronto Press, 1985), pp. 133-182.

5. For a more recent treatment that combines both analytical and case law review, see Peter Hogg, "Federalism Fights the Charter of Rights", paper presented at the "Conference on Federalism and the Quest for Political Community" in honour of Donald Smiley, York University, May 6-8, 1988.

6. See F.L. Morton and Michael J. Withey, "Charting the Charter: 1982-1985 - A Statistical Analysis"', (1987) Canadian Human Rights Yearbook 65.

7. This study included all Charter cases, not just Court of Appeal decisions. In 438 challenges to federal statutes, 101 resulted in nullifications. There were 192 challenges to provincial statutes, resulting in 57 nullifications. See Morton and Withey, “Charting the Charter, 1982-1985', supra, note 6. 
While this earlier study disclosed that "statute cases" constitute less than a third of all Charter litigation, it told us very little about these cases. Indeed, it raised a host of new questions about Charter challenges to statutes. Which statutes have been challenged most often and most successfully under the Charter? What Charter rights have been responsible for the most nullifications? Have most Charter nullifications been procedural or substantive in character? Have older laws been more susceptible to Charter challenges than more recently enacted statutes? Have provincial statutes been more susceptible to Charter challenges than federal statutes? Have some provinces been more affected than others? Have some provincial Courts of Appeal been more activist than others? Finally, is Charter activism - the willingness of Canadian judges to strike down statutes under the Charter - increasing?

To date most attempts to answer these questions have focussed only on the Supreme Court of Canada's Charter decisions. This was the approach taken by Professor Peter Russell in his recent assessment of the impact of the Charter on legislative policy-making. Russell found that the Supreme Court had struck down only 10 statutes, 7 federal and 3 provincial. He concluded that the Charter has had a minimal impact on statutes and has not unduly prejudiced provincial autonomy. ${ }^{8}$

While this approach may accurately describe the Charter jurisprudence of the Supreme Court, it does not capture the broader impact of the Charter on Parliament and the ten provincial legislatures. The Supreme Court's Charter decisions represent only the " "tip of the iceberg". A recent study found that there are over six thousand decisions made by provincial courts of appeal annually. ${ }^{9}$ Only four to five hundred (less than 10\%) of these are appealed to the Supreme Court, and the Supreme Court grants leave to appeal for only about one hundred of these. This means that less than $2 \%$ of all provincial court of appeal decisions are reviewed by the Supreme Court. This figure is accurate for Charter cases as well. There have been almost 5,000 reported Charter decisions since 1982, but the Supreme Court has decided only about one hundred on appeal.

This study adopts a broader scope than the Russell study, and discovers a very different picture of the Charter's impact on legislative activity. Using the Charter of Rights Database at the University of Calgary, this study identifies and analyzes all reported Court of Appeal (federal and provincial) decisions from 1982 through 1988 in which a statute is ruled invalid, in whole or in part.

\section{THE CASES}

From 1982 through 1988, 80 Charter decisions, made by the Supreme Court of Canada or one of the provincial Courts of Appeal, have served to declare a total

8. Peter H. Russell, “Canada's Charter of Rights and Freedoms: A Political Report", (Autumn 1988) Public Law 385 at 392.

9. Figures provided by Professor Peter McCormick, University of Lethbridge, from his study of provincial Courts of Appeal. 
of 63 statutes ${ }^{10}$ null and void. The discrepancy between the number of cases (80) and the number of statutes nullified (63) is explained by the fact that the same statute may be declared invalid in more than one decision. "Of the 63 nullified statutes, 31 are provincial and 32 federal. These are presented in Table 1 , which also presents the subject matter of the nullified provision, the Charter claim(s) that were successful, whether the impugned provision was procedural or substantive in character, its slate of enactment (royal assent), ${ }^{12}$ and the date the case was decided.

10. We use the term "statute" to include subsections of statutes and also regulations. This usage is potentially misleading, since there can be important differences between striking down an entire statute as opposed to anly one subsection. However, it would be equally misleading to lump together the fifteen decisions nullifying different sections of the Criminal Code. We concluded that this latter approach risks understating the Charter's impact on statutes more than our approach risks overstating the effect. For the record, however, our findings can be restated as follows. The courts have struck down thirty sections or subsections of fourteen federal statutes and parts of two regulations; and twenty-five sections or subsections of twenty provincial statutes and parts of six regulations.

11. For example, s. 8 of the Narcotic Control Act was declared invalid in seven different cases, but counts as only one nullification. Also not counted as nullifications are five Court of Appeal decisions that nullify a statute but are later reversed by the Supreme Court.

12. In some cases the measure enacted on that date is not identical with the provision that is subsequently nullified, but is comparable in substance and purpose. Subsequent amendments of a purely technical nature have been disregarded. The amendments noted in Table 1 are those that altered the substance of the provision, but not in a manner that affected the present case. 
TABLE 1

\section{Appeal Court Charter Decisions Nullifying Statutes, 1982-1988}

FEDERAL STATUTES

\begin{tabular}{|c|c|c|c|c|c|c|c|}
\hline CASE NAME 13 & $\begin{array}{l}\text { APPEAL } \\
\text { COURT }\end{array}$ & STATUTE & $\begin{array}{l}\text { SUBJECT } \\
\text { MATTER }\end{array}$ & $\begin{array}{l}\text { DATE OF } \\
\text { ENACTMENT }\end{array}$ & $\begin{array}{l}\text { CHARTER } \\
\text { SECTION }\end{array}$ & $\begin{array}{l}\text { DATE } \\
\text { DECIDED }\end{array}$ & $\begin{array}{l}\text { SUBSTANCE/ } \\
\text { PROCEDURE }\end{array}$ \\
\hline Smith v. The Queen & SCC* & Narcotic Control Act s.5(2) & Minimum sentence & 1961 & 12 & June 1987 & Procedure \\
\hline $\begin{array}{l}R . \text { v. Cook } \\
R . \text { v. Carroll } \\
R . \text { v. Oakes } \\
R . \text { v. Oakes } \\
R . \text { v. Stanger } \\
R . \text { v. Stock } \\
\text { Re Pizzuro and Casemore }\end{array}$ & $\begin{array}{l}\text { NS } \\
\text { PEI } \\
\text { ONT } \\
\text { SCC } \\
\text { ALTA } \\
\text { BC } \\
\text { ONT }\end{array}$ & $\begin{array}{l}\text { Narcotic Control Act s.8 } \\
\text { Narcotic Control Act s.8 } \\
\text { Narcotic Control Act s.8 } \\
\text { Narcotic Control Act s.8 } \\
\text { Narcotic Control Act s.8 } \\
\text { Narcotic Control Act s.8 } \\
\text { Narcotic Control Act s.8 }\end{array}$ & $\begin{array}{l}\text { Reverse Onus } \\
\text { Reverse Onus } \\
\text { Reverse Onus } \\
\text { Reverse Onus } \\
\text { Reverse Onus } \\
\text { Reverse Onus } \\
\text { Reverse Onus }\end{array}$ & $\begin{array}{l}1961 \\
1961 \\
1961 \\
1961 \\
1961 \\
1961 \\
1961\end{array}$ & $\begin{array}{l}11(d) \\
11(d) \\
11(d) \\
11(d) \\
11(d) \\
11(d) \\
11(d)\end{array}$ & $\begin{array}{ll}\text { Mar. } & 1983 \\
\text { Feb. } & 1983 \\
\text { Feb. } & 1983 \\
\text { Feb. } & 1986 \\
\text { July } & 1983 \\
\text { Dec. } & 1983 \\
\text { Jan. } & 1984\end{array}$ & $\begin{array}{l}\text { Procedure } \\
\text { Procedure } \\
\text { Procedure } \\
\text { Procedure } \\
\text { Procedure } \\
\text { Procedure } \\
\text { Procedure }\end{array}$ \\
\hline
\end{tabular}

*Supreme Court of Canada

13. FEDERAL CASES: Smith v. The Queen (1987), 40 D.L.R. (4th) 435 (S.C.C.); R. v. Cook (1983) 147 D.L.R. (3rd) 687 (N.S.C.A.); R. v. Carroll (1983), 147 D.L.R. (3rd) 92 (P.E.I.C.A.); $R$ v. Oakes (1983), 145 D.L.R. (3rd) 123 (Ont. C.A.); $R$. v. Oakes (1986), 26 D.L.R. (4th) 200 (S.C.C.); R. v. Stanger (1983), 2 D.L.R. (4th) 121 (Alta. C.A.); R. v. Stock (1983), 10 C.C.C. (3rd) 319 (B.C.C.A.); Re Pizzuro and Casemore and The Queen (1984), 6 D.L.R. (4th) 189 (Ont. C.A.); R. v. Rao (1984), 9 D.L.R. (4th) 542 (Ont. C.A.); R. v. Noble (1984), 14 D.L.R. (4th) 216 (Ont. C.A.); Hamill v. The Queen (1987), 38 D.L.R. (4th) 611 (S.C.C.); R. v. LaPlante (1987), 48 D.L.R. (4th) 615 (Sask. C.A.); R. v. Metro News (1986), 32 D.L.R. (4th) 321 (Ont. C.A.); R. v. Skinner (1987), 35 C.C.C. (3rd) 203 (N.S.C.A.); Vaillancourt v. The Queen (1987), 47 D.L.R. (4th) 399 (S.C.C.); R. v. Giff (1988), 42 C.C.C. (3rd) 524 (Ont. C.A.); R. v. Martineau (1988), 43 C.C.C. (3rd) 417 (Alta. C.A.); R. v. Logan (1988), 67 O.R. (2nd) 87 (C.A.); R. v. Gough (1985), 18 C.C.C. (3rd) 453 (Ont. C.A.); Morgentaler v. The Queen (1988), 44 D.L.R. (4th) 385 (S.C.C.); R. v. Keegstra (1988), 43 C.C.C. (3rd) 150 (Alta. C.A.); R. v. Singh (1987), 41 C.C.C. (3rd) 278 (Alta. C.A.); Re Boyle and The Queen (1983), 5 C.C.C. (3rd) 193 (Ont. C.A.); R. v. Driscoll (1987), 38 C.C.C. (3rd) 28 (Alta. C.A.); Canadian Newspapers Co. Ld. v. A.G. Canada (1985), 16 D.L.R. (4th) 642 (Ont. C.A.); R. v. Bryant (1984), 15 D.L.R. (4th) 66 (Ont. C.A.); Southam Inc. v. Hunter (1983), 147 D.L.R. (3rd) 420 (Alta. C.A.); Hunter v. Southam Inc. (1984), 11 D.L.R. (4th) 641 (S.C.C.); Minister of National Revenue v. Kruger Inc. (1984), [1984] 2 F.C. 535 (C.A.); F.K. Clayton Group Inc. v. Minister of National Revenue (1988), [1988] 2 F.C. 467 (C.A.); R. v. Big M Drug Mart Lid. (1983), 5 D.L.R. (4th) 121 (Alta. C.A.); R. v. Big M Drug Mart Ldd. (1985), 18 D.L.R. (4th) 321 (S.C.C.); Re Singh and Minister of Employment \& Immigration (1985), 17 D.L.R. (4th) 422 (S.C.C.); $R$. v. Ireco Canada II Inc. (1988), 43 C.C.C. (3rd) 482 (Ont. C.A.); $R e$ Luscher and Deputy Minister, Revenue Canada (1985), 17 D.L.R. (4th) 503 (F.C.A.); Re Southam Inc. and The Queen (1983), 146 D.L.R. (3rd) 408 (Ont. C.A.); International Fund for Animal Welfare Inc. v. The Queen (1988), 45 C.C.C. (3rd) 457 (F.C.A.); R. v. Beare and Higgins (1987), 40 D.L.R. (4th) 600 (Sask. C.A.); Zutphen Brothers Construction Ltd. v. Dywidag Systems International, Canada Lid. (1987), 35 D.L.R. (4th) 433 (N.S.C.A.); Re Tetrault-Gadoury and Canada Employment \& Immigration Commission (1988), 53 D.L.R. (4th) 384 (F.C.A.); A. G. Canada v. Weatherall (1988), [1989] 1 F.C. 18 (C.A.); Millar v. The Queen (July, 1988) (F.C.A.) [unreported]. 


\begin{tabular}{|c|c|c|c|c|c|c|c|c|}
\hline $\begin{array}{l}\text { R. v. Rao } \\
\text { R. v. Noble } \\
\text { Hamill v. The Queen }\end{array}$ & $\begin{array}{l}\text { ONT } \\
\text { ONT } \\
\text { SCC }\end{array}$ & $\begin{array}{l}\text { Narc. Control Act s. } 10(1)(a) \\
\text { Narc. Control Act s. } 10(1)(a) \\
\text { Narc. Control Act s. } 10(1)(a)\end{array}$ & $\begin{array}{l}\text { Warrantless Search } \\
\text { Warrantless Search } \\
\text { Warrantless Search }\end{array}$ & $\begin{array}{l}1961 \\
1961 \\
1961\end{array}$ & $\begin{array}{l}8 \\
8 \\
8^{14}\end{array}$ & $\begin{array}{l}\text { May } \\
\text { Nov. } \\
\text { Apr. }\end{array}$ & $\begin{array}{l}1984 \\
1984 \\
1987\end{array}$ & $\begin{array}{l}\text { Procedure } \\
\text { Procedure } \\
\text { Procedure }\end{array}$ \\
\hline $\begin{array}{l}R . \text { v. LaPlante } \\
R . \text { v. Noble } \\
R \text { v. Stanger }\end{array}$ & $\begin{array}{l}\text { SASK } \\
\text { ONT } \\
\text { ALTA }\end{array}$ & $\begin{array}{l}\text { Food \& Drugs Act s.37(1)(a) } \\
\text { Food \& Drugs Act s.37(1)(a) } \\
\text { Food \& Drugs Act s.43(2) }\end{array}$ & $\begin{array}{l}\text { Illegal Search } \\
\text { Illegal Search } \\
\text { Reverse Onus }\end{array}$ & $\begin{array}{l}1961 \\
1961 \\
1969\end{array}$ & $\begin{array}{l}8 \\
8 \\
11(d)\end{array}$ & $\begin{array}{l}\text { Nov. } \\
\text { Nov. } \\
\text { July }\end{array}$ & $\begin{array}{l}1987 \\
1984 \\
1983\end{array}$ & $\begin{array}{l}\text { Procedure } \\
\text { Procedure } \\
\text { Procedure }\end{array}$ \\
\hline $\begin{array}{l}\text { R. v. Metro News } \\
R . \text { v. Skinner } \\
\text { Vaillancourt v. Queen } \\
R . \text { v. Giff } \\
\text { R. v. Martineau } \\
\text { R. v. Logan } \\
\text { R. v. Gough } \\
\text { Morgentaler v. Queen } \\
\text { R. v. Keegstra } \\
\text { R. v. Singh } \\
\text { Re Boyle \& The Queen } \\
R . \text { v. Driscoll } \\
\text { Cdn. Newspapers Co. Lid. } \\
\text { v. A.G. Canada }\end{array}$ & $\begin{array}{l}\text { ONT } \\
\text { NS } \\
\text { SCC } \\
\text { ONT } \\
\text { ALTA } \\
\text { ONT } \\
\text { ONT } \\
\text { SCC } \\
\text { ALTA } \\
\text { ALTA } \\
\text { ONT } \\
\text { ALTA } \\
\text { ONT }\end{array}$ & $\begin{array}{l}\text { Criminal Code s.159(6) } \\
\text { Criminal Code s.195.1(1)(c) } \\
\text { Criminal Code s.213(d) } \\
\text { Criminal Code s.213(a) } \\
\text { Criminal Code s.213(a) } \\
\text { Criminal Code } s .21(2) \\
\text { Criminal Code s.247(3) } \\
\text { Criminal Code s.251 } \\
\text { Criminal Code s.281.2 } \\
\text { Criminal Code s.281.2(3)(a) } \\
\text { Criminal Code s.308(b)(ii) } \\
\text { Criminal Code s.312(2) } \\
\text { Criminal Code s.320(4) } \\
\text { Criminal Code s.442(3) }\end{array}$ & $\begin{array}{l}\text { Absolute liability } \\
\text { Solicit prostitution } \\
\text { Constructive murder } \\
\text { Constructive murder } \\
\text { Constructive murder } \\
\text { Party to an offense } \\
\text { Reverse onus } \\
\text { Abortion } \\
\text { Promoting Hatred } \\
\text { Reverse onus } \\
\text { Reverse onus } \\
\text { Reverse onus } \\
\text { Reverse onus } \\
\text { Publication ban }\end{array}$ & $\begin{array}{l}1949 \\
1972 \\
1892 \\
1892 \\
1892 \\
1892 \\
1954 \\
1969 \\
1970 \\
1970 \\
1892 \\
1972 \\
1954 \\
1892, \\
\text { amend. } \\
1980-83\end{array}$ & $\begin{array}{l}7 \\
2(\text { b) } \\
7 \& 11(d) \\
7 \& 11(d) \\
7 \& 11(d) \\
7 \\
11(d) \\
7 \\
2(\text { b) } \\
11(d) \\
11(d) \\
11(d) \\
11(d) \\
2(\text { b) }\end{array}$ & $\begin{array}{l}\text { Sept. } \\
\text { May } \\
\text { Dec. } \\
\text { June } \\
\text { Aug. } \\
\text { Dec. } \\
\text { Jan. } \\
\text { Jan. } \\
\text { June } \\
\text { June } \\
\text { Dec. } \\
\text { June } \\
\text { Aug. } \\
\text { Feb. }\end{array}$ & $\begin{array}{l}1986 \\
1987 \\
1987 \\
1988 \\
1988 \\
1988 \\
1985 \\
1988 \\
1988 \\
1988 \\
1987 \\
1983 \\
1987 \\
1985\end{array}$ & $\begin{array}{l}\text { Procedure } \\
\text { Substance } \\
\text { Procedure's } \\
\text { Procedure } \\
\text { Procedure } \\
\text { Procedure } \\
\text { Procedure } \\
\text { Proc. \& Sub. } \\
\text { Substance } \\
\text { Procedure } \\
\text { Procedure } \\
\text { Procedure } \\
\text { Procedure } \\
\text { Procedure }\end{array}$ \\
\hline R. v. Bryant & ONT & Criminal Code s.526.1 & Waiver of jury trial & 1976 & 7 & Nov. & 1984 & Procedure \\
\hline Southam v. Hunter & ALTA & $\begin{array}{l}\text { Combines Investigation Act } \\
\text { ss. 10(1)\&(3) }\end{array}$ & Search \& seizure & 1952 & 8 & Jan. & 1983 & Procedure \\
\hline Hunter v. Southam & SCC & $\begin{array}{l}\text { Combines Investigation Act } \\
\text { ss.10(1)\&(3) }\end{array}$ & Search \& seizure & 1952 & 8 & Sept. & 1984 & Procedure \\
\hline $\begin{array}{l}\text { Min. Nat'l Revenue } \\
\text { v. Kruger Inc. }\end{array}$ & $\mathrm{FCA}^{* *}$ & Income Tax Act s.231(4) & Illegal search & 1971 & 8 & Aug. & 1984 & Procedure \\
\hline $\begin{array}{l}\text { F.K. Clayton Group Led. } \\
\text { v. Min. Nat'l Revenue }\end{array}$ & FCA & $\begin{array}{l}\text { Income Tax Act ss.231(1)(d) } \\
\& 231(2)\end{array}$ & Illegal seizure & $1980-83$ & 8 & Mar. & 1988 & Procedure \\
\hline
\end{tabular}

**Federal Court of Appeal

14. This section of the Narcotic Control Act was repealed by the Government before the case reached the Supreme Court of Canada because of the apparent conflict with $\mathbf{s . 8}$ of the Charter. The Crown conceded that writs of assistance violated s.8.

15. Section 213(d) could be interpreted as either procedural or substantive in character. We have chosen to treat it a related cases - Logan, Marnineau, and Giff - as procedural because the Charter infraction is based on the reduced burden of proof placed on the Crown. 


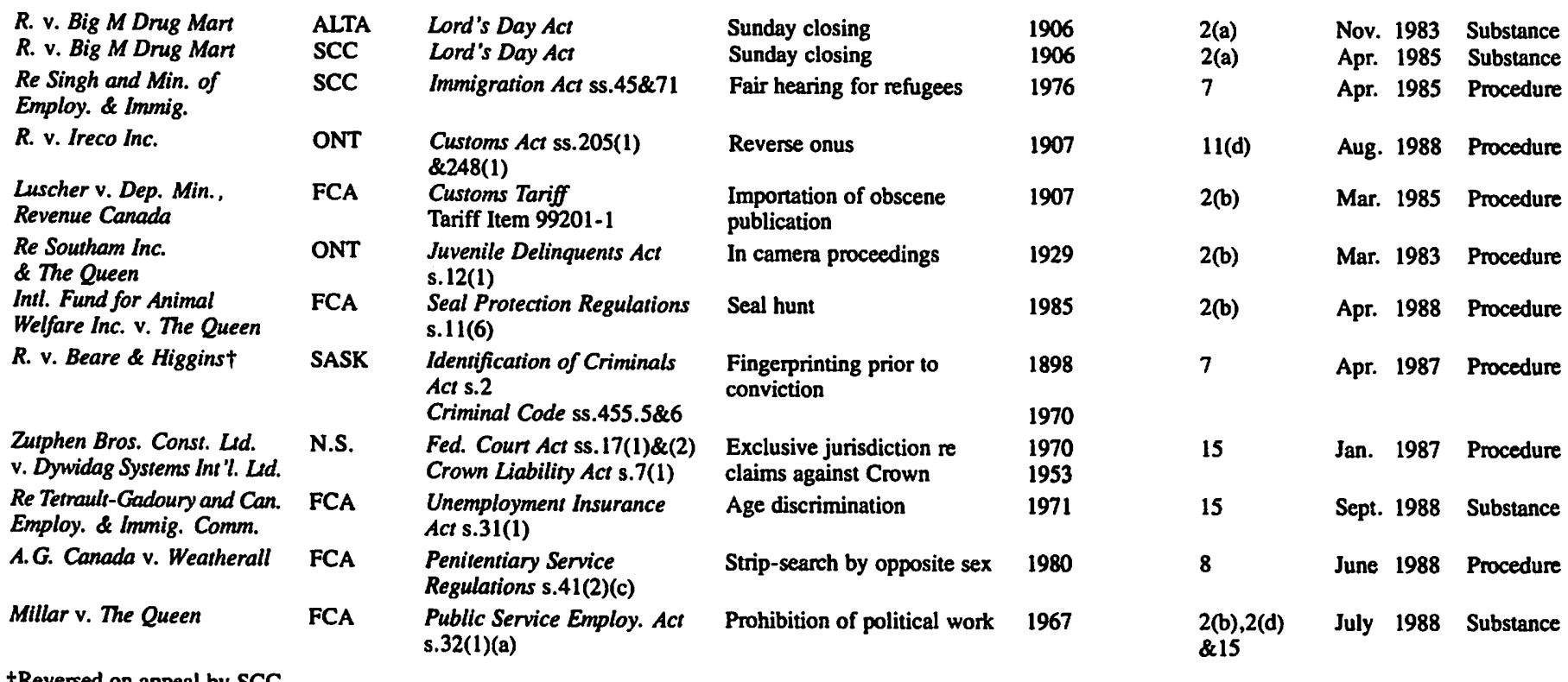

[42 cases; 33 statutes, less 1 SCC reversal, equals 32 statutes] 


\section{PROVINCIAL STATUTES}

\section{CASE NAME}

Re Reynolds and A.G. BC Ref. Re Motor Vehicle Act Ref. Re Motor Vehicle Act

\section{R. v. Alston \\ R. v. Robson \\ R. v. Racette \\ R. v. Burt}

Que. Assoc. of Protestant School Bds. v. A.G. Oue.

Que. Assoc. of Protestant School Bds. v. A.G. Que.

$\begin{array}{ll}\text { APPEAL } & \text { STATUTE } \\ \text { COURT } & \\ \text { BC } & \text { Election Act } \mathrm{s.3(1)(b)} \\ \text { BC } & \text { Motor Vehicle Act s.94(2) } \\ \text { SCC } & \begin{array}{l}\text { Motor Vehicle Act } \\ \text { (BC) s.94(2) }\end{array} \\ \text { BC } & \text { Motor Vehicle Act s.88(2) } \\ \text { BC } & \text { Motor Vehicle Act s.214(2) } \\ \text { SASK } & \text { Vehicles Act s.168 } \\ \text { SASK } & \text { Vehicles Act s.253 } \\ \text { QUE } & \text { Chartre de la Langue } \\ \text { SCC } & \begin{array}{l}\text { Francaise ch.VIII } \\ \text { Chartre de la Langue }\end{array} \\ & \text { Francaise ch.VIII }\end{array}$

SUBJECT

MATTER

Denial of vote to convicts

Absolute liability

Absolute liability

Imputation of knowledge

Roadside suspension

Blood samples

Absolute liability

Minority language education

rights

Minority language education rights

\begin{tabular}{|c|c|c|c|}
\hline $\begin{array}{l}\text { DATE OF } \\
\text { ENACTMENT }\end{array}$ & $\begin{array}{l}\text { CHARTER } \\
\text { SECTION }\end{array}$ & $\begin{array}{l}\text { DATE } \\
\text { DECIDED }\end{array}$ & $\begin{array}{l}\text { SUBSTANCE/ } \\
\text { PROCEDURE }\end{array}$ \\
\hline 1874 & 3 & May 1984 & Substance \\
\hline $\begin{array}{l}1981 \\
1981\end{array}$ & $\begin{array}{l}7 \\
7\end{array}$ & $\begin{array}{ll}\text { Feb. } & 1983 \\
\text { Dec. } & 1985\end{array}$ & $\begin{array}{l}\text { Procedure } \\
\text { Procedure }\end{array}$ \\
\hline $\begin{array}{l}1981 \\
1970 \\
1983 \\
1978\end{array}$ & $\begin{array}{l}7 \\
7 \\
7 \& 8 \\
7\end{array}$ & $\begin{array}{ll}\text { Oct. } & 1985 \\
\text { Mar. } & 1985 \\
\text { Jan. } & 1988 \\
\text { Oct. } & 1987\end{array}$ & $\begin{array}{l}\text { Procedure } \\
\text { Procedure } \\
\text { Procedure } \\
\text { Procedure }\end{array}$ \\
\hline 1977 & 23 & June 1983 & Substance \\
\hline 1977 & 23 & July 1984 & Substance \\
\hline
\end{tabular}

16. PROVINCIAL CASES: Re Reynolds and A.G. British Columbia (1984), 11 D.L.R. (4th) 380 (B.C.C.A.); Reference Re Section 94(2) of the Motor Vehicle Act (1983), 147 D.L.R. (4th) 539 (B.C.C.A.); Reference Re Section 94(2) of the Motor Vehicle Act (1985), 24 D.L.R. (4th) 536 (S.C.C.); R. v. Alston (1985), 22 C.C.C. (3rd) 563 (B.C.C.A.); R. v. Robson (1985), 19 D.L.R. (4th) 112 (B.C.C.A.); R. v. Racette (1988), 48 D.L.R. (4th) 412 (Sask. C.A.); R. v. Bur (1987), 38 C.C.C. (3rd) 299 (Sask. C.A.); Quebec Association of Protestant School Boards v. A. G. Quebec (1983), 1 D.L.R. (4th) 573 (Que. C.A.); Quebec Association of Protestant School Boards v. A.G. Quebec (1984), 10 D.L.R. (4th) 321 (S.C.C.); A.G. Quebec v. La Chaussure Brown's Inc. (1986), 36 D.L.R. (4th) 374 (Que. C.A.); Ford v. A.G. Quebec (1988), 54 D.L.R. (4th) 577 (S.C.C.); Devine v. A.G. Quebec (1988), 55 D.L.R. (4th) 641 (S.C.C.); Alliance des Professeurs de Montreal v. A.G. Quebec (1985), 21 D.L.R. (4th) 354 (Que. C.A.); Reference Re Education Act of Ontario and Minority Language Education Rights (1984), 10 D.L.R. (4th) 491 (Ont. C.A.); Zylberberg v. Sudbury Board of Education (1988), 52 D.L.R. (4th) 577 (Ont. C.A.); $R$ v. Videoflicks Lid. (1984), 14 D.L.R. (4th) 10 (Ont. C.A.); Re Skapinker and Law Society of Upper Canada (1983), 3 C.C.C. (3rd) 213 (Ont. C.A.); Black v. Law Society of Alberta (1986), 27 D.L.R. (4th) 527 (Alta. C.A.); Re MacAusland and The Queen (1985), 19 C.C.C. (3rd) 365 (P.E.I.C.A.): R. v. I.D.D. (1987), 60 Sask. R. 72 (C.A.); R. v. Sheppard (1983), 11 C.C.C. (3rd) 276 (Nfld. C.A.); Re RWDSU and Government of Saskatchewan (1985), 19 D.L.R. (4th) 609 (Sask. C.A.); Re Blainey and Ontario Hockey Association (1986), 26 D.L.R. (4th) 728 (Ont. C.A.); Harrison v. University of British Columbia (1988), 49 D.L.R. (4th) 687 (B.C.C.A.); Stoffman v. Vancouver General Hospital (1988), 49 D.L.R. (4th) 727 (B.C.C.A.); Sniders v. A.G. Nova Scotia (1988), 88 N.S.R. (2nd) 91 (C.A.); Wilson v. Medical Services Commission of British Columbia (1988), 30 B.C.L.R. (2nd) 1 (C.A.); Thwaites v. Medical Officer in Charge (1988), 48 D.L.R. (4th) 338 (Man. C.A.); Re Rocket and Royal College of Dental Surgeons of Ontario (1988), 49 D.L.R. (4th) 641 (Ont. C.A.); Re Grier and Alberia Optometric Association (1987), 42 D.L.R. (4th) 327 (Alta. C.A.); Corporation Professionnelle des Medecins de Quebec v. Thibault (1988), [1988] 1 S.C.R. 1033; Colangelo v. Ciry of Mississauga (1988), 66 O.R. (2nd) 29 (C.A.); Basile v. A.G. Nova Scotia (1984), 11 D.L.R. (4th) 219 (N.S.C.A.); R. v. Belliveau \& Losier (1986), 75 N.B.R. (2nd) 18 (C.A.); Inwin Toy v. A.G. Quebec (1986), 32 D.L.R. (4th) 641 (Que. C.A.); Gorzen v. Liz (1988), 66 Sask. R. 211 (C.A.); Williams v. Haugen (13 December 1988) (Sask. C.A.) \{unreported]; Re Edmonton Journal and A.G. Alberta (1987), 41 D.L.R. (4th) 502 (Alta. C.A.). 


\begin{tabular}{|c|c|c|c|c|c|c|c|c|}
\hline $\begin{array}{l}\text { A.G. Que. v. La } \\
\text { Chaussure Brown's }\end{array}$ & QUE & $\begin{array}{l}\text { Chartre de la Langue } \\
\text { Francaise ss.58\&69 }\end{array}$ & $\begin{array}{l}\text { Language of advertising; } \\
\text { French-only signs }\end{array}$ & 1977 & 2(b) & Dec. & 1986 & Substance \\
\hline Ford v. A.G. Que. & SCC & $\begin{array}{l}\text { Chartre de la Langue } \\
\text { Francaise ss.58\&69 }\end{array}$ & $\begin{array}{l}\text { Language of advertising; } \\
\text { French-only signs }\end{array}$ & 1977 & 2(b) & Dec. & 1988 & Substance \\
\hline Devine v. A.G. Que. & SCC & $\begin{array}{l}\text { Chartre de la Langue } \\
\text { Francaise ss.59-61\&Regs }\end{array}$ & $\begin{array}{l}\text { French as language } \\
\text { of business }\end{array}$ & 1977 & 2(b) & Dec. & 1988 & Substance \\
\hline $\begin{array}{l}\text { Alliance des Professeurs } \\
\text { v. A.G. Quebec }\end{array}$ & QUE & $\begin{array}{l}\text { Act Respecting the } \\
\text { Constitution Act, } 1982\end{array}$ & $\begin{array}{l}\text { Section } 33 \text { Override of } \\
\text { ss. } 2 \& 7-15\end{array}$ & 1982 & 33 & June & 1985 & Procedure \\
\hline $\begin{array}{l}\text { Ref. Re Ontario } \\
\text { Education Act }\end{array}$ & ONT & Education Act ss.258\&261 & $\begin{array}{l}\text { Minority language education } \\
\text { rights }\end{array}$ & 1982 & 23 & June & 1984 & Substance \\
\hline $\begin{array}{l}\text { Zylberberg v. Sudbury } \\
\text { Bd. of Ed. }\end{array}$ & ONT & $\begin{array}{l}\text { Education Act } \operatorname{Reg} .704 / 78 \\
\text { s.28(1) }\end{array}$ & School prayer & 1978 & 2(a) & Sept. & 1988 & Substance \\
\hline R. v. Videoflicks $\dagger$ & ONT & $\begin{array}{l}\text { Retail Business Holidays Act } \\
\mathrm{s.2}\end{array}$ & Sunday closing & 1975 & 2(a) & Sept. & 1984 & Substance \\
\hline $\begin{array}{l}\text { Re Skapinker and Law } \\
\text { Society of Upper Canada }\end{array}$ & ONT & Law Society Act s.28c & Citizenship requirement & 1970 & 6 & Jan. & 1983 & Substance \\
\hline $\begin{array}{l}\text { Black v. Law Society } \\
\text { of Alberta }\end{array}$ & ALTA & $\begin{array}{l}\text { Legal Profession Act } \\
\text { Rules 75B\&154 }\end{array}$ & Interprovincial law firms & 1983 & $\begin{array}{l}6(2)(b) \\
\& 2(d)\end{array}$ & Mar. & 1986 & Substance \\
\hline $\begin{array}{l}\text { Re MacAusland \& } \\
\text { The Queen }\end{array}$ & PEI & Liquor Control Act s.58 & Illegal search & 1967 & 8 & Mar. & 1985 & Procedure \\
\hline R. v. I.D.D. & SASK & Liquor Act s.131 & Search authorization & 1978 & 8 & Oct. & 1987 & Procedure \\
\hline R. v. Sheppard & NFLD & Wild Life Act s. 10(2) & Illegal search & 1951 & 8 & Jan. & 1983 & Procedure \\
\hline $\begin{array}{l}\text { Re RWDSU and Govt. of } \\
\text { Saskatchewant } \dagger \\
\text { [Dainy Workers] }\end{array}$ & SASK & $\begin{array}{l}\text { Dairy Workers } \\
\text { (Maintenance of Operations) } \\
\text { Act }\end{array}$ & Back to work order & 1984 & 2(d) & June & 1985 & Substance \\
\hline $\begin{array}{l}\text { Re Blainey and Ont. } \\
\text { Hockey Assoc. }\end{array}$ & ONT & Human Rights Code s.19(2) & $\begin{array}{l}\text { Sex discrimination } \\
\text { [boys-only hockey] }\end{array}$ & 1981 & 15 & April & 1986 & Substance \\
\hline Harrison v. UBC & BC & Human Rights ACt s.l & $\begin{array}{l}\text { Mandatory retirement } \\
\text { [age discrimination] }\end{array}$ & 1981 & 15 & Jan. & 1988 & Substance \\
\hline $\begin{array}{l}\text { Stoffman v. Vancouver } \\
\text { General Hospital }\end{array}$ & BC & Hospitals Act Reg.5:04 & $\begin{array}{l}\text { Mandatory retirement } \\
\text { [age discrimination] }\end{array}$ & 1979 & 15 & Jan. & 1988 & Substance \\
\hline Sniders v. A.G. Nova Scotia & NS & $\begin{array}{l}\text { Human Rights Act } \\
\text { s.11B(1)(a)\&(3) }\end{array}$ & $\begin{array}{l}\text { Mandatory retirement } \\
\text { [age discrimination] }\end{array}$ & 1974 & 15. & Dec. & 1988 & Substance \\
\hline
\end{tabular}

†Reversed on appeal by the Supreme Court of Canada. 
Wilson v. Medical Services Commission of B.C.

BC

Medical Services Act s.8.1\&8.2 and Regs.

Thwaites v. Medical Officer MAN In Charge, Psychiatric Facility Re Rocket and Royal College ONT of Dental Surgeons

Re Grier and Alberta Optometric Assoc.

Corp. des Medecins

de Que. v. Thibault

Colangelo v. Mississauga

Basile v. A.G. Nova Scotia

ALTA

Mental Health Act s.9

Health Disciplines Act Reg. 447, s.37

Alberta Optometric Assoc.

bylaw 50(a)

SCC Summary Convictions ACr

$$
\text { [Que.] s.75 }
$$

ONT

Municipal Act ss.284(5)\&(6)

NS

Direct Sellers Licensing

\& Regulation Act,

Rules \& Regs. s.19

R. v. Belliveau \& Losier

Irwin Toy v. A.G. Quebec $†$

NB

Tobacco Tax Act

ss.2.2(3)\&(4)

QUE

Consumer Protection Act

ss.248\&249

Gorzen v. Litz

SASK

Children of Unmarried

Parents ACt s.34

Williams v. Haugen

SASK

Children of Unmarried

Parents Act s.9

ALTA

Judicature Act s.30 and A.G. Alberta \&

A.G. Canada17

†Reversed on appeal by the Supreme Court of Canada.

[38 cases; 35 statutes, less 4 SCC reversals, equal 31 statutes]
Restrictions on doctors'

ability to choose where

to work

Compulsory Admissions

Advertising

Advertising

Appeal procedure

Notice requirements re injuries caused by snow

Licensing of out-of-province salesmen

Legal sale of cigarettes

[warrantless search]

Prohibition of advertising

aimed at children under 13

Equality regarding evidence

of maintenance

Discrimination against single

mothers and illegitimate

children

Reporting matrimonial

litigation
1985

7

Aug. 1988 Substance \&

Procedure

1970

9

Feb. 1988 Procedure

1980

2(b)

2(b)

April 1988 Substance

1980

July 1987 Substance

1977

11(h)

1903

15

May 1988 Procedure

1975

6(2)

Sept. 1988 Substance

1983

8

Mar. 1984 Substance

1978

2(b)

1973

1973

1935

2(b)

Oct. 1986 Procedure

Sept. 1986 Substance

Apr. 1988 Procedure

Dec. 1988 Substance

July 1987 Substantive

17. This case technically involves a "constitutional exemption" - the enforcement of the Act is suspended to protect the Charter rights involved on a case by case basis. We have interpreted this remedy as functionally equivalent to a partial nullification for the purposes of this case. 
Table 1 confirms that the Criminal Code has been the federal statute most affected by the Charter. There have been 15 Charter decisions nullifying 14 different sections of the Criminal Code. These include Morgentaler, ${ }^{18}$ which struck down the abortion law; Keegstra ${ }^{19}$ which nullified two different provisions of the "racial hatred" law; Vaillancourt, ${ }^{20}$ which struck down the offence of "constructive murder"; Skinner, ${ }^{21}$ which struck down the anti-soliciting (prostitution) law; and five different "reverse onus" sections of the Code.

The second most affected federal statute was the Narcotic Control Act, which had three sections declared invalid: one "reverse onus" provision and two warrantless search clauses. Two sections of the Food and Drugs Act were also struck down, one for illegal search practices, the other for a "reverse onus" clause.

The types of provincial statutes affected by the Charter were predictably more diverse. Five different provisions of provincial laws that dealt with drinking and driving were struck down. Three different provisions of provincial education acts were declared invalid, two dealing with minority language instruction and one with voluntary school prayer. There were also three different provincial mandatory retirement provisions struck down. The other 20 nullified provincial laws dealt with diverse policy issues.

\section{WHICH CHARTER RIGHTS ARE RESPONSIBLE FOR THE MOST NULLIFICATIONS?}

Table 2 indicates which sections of the Charter and which categories of rights have had the greatest effect on Canadian legislation. The legal rights provisions of the Charter have clearly been the basis for the most nullifications of statutes. Of the $89^{22}$ successful Charter arguments against federal and provincial statutes, 49 were based on legal rights. Most of these (35) involved federal statutes. Fundamental freedoms (s.2) and equality rights (s.15) accounted for 22 and 10 nullifications, respectively.

18. (1988) 44 D.L.R. (4th) 385 (S.C.C.).

19. (1988) 43 C.C.C. (3d) 150 (Alta. C.A.).

20. (1987) 47 D.L.R. (4th) 399 (S.C.C.).

21. (1987) 35 C.C.C. (3d) 203 (N.S.C.A.).

22. There are more Charter arguments or claims than Charter cases, since a single case may contain several Charter claims. Millar, for example, dealt with three different Charter claims: s.2(b), s.2(d) and s.15. 


\section{TABLE $2^{23}$ \\ Charter Rights that served as basis for nullifying a statute}

Category
of Rights

Fundamental Freedoms

Democratic Rights

Mobility Rights

Legal Rights

\section{Charter}

sections

2(a)

2(b)

2(d)

3

6

7

8

9

11(d)

11(h)

12

\begin{tabular}{ccc}
$\begin{array}{c}\text { Federal } \\
\text { statutes }\end{array}$ & $\begin{array}{c}\text { Provincial } \\
\text { statutes }\end{array}$ & $\begin{array}{c}\text { Total } \\
\text { cases }\end{array}$ \\
$2^{24}$ & $2^{25}$ & 4 \\
$7^{26}$ & $8^{27}$ & 15 \\
$1^{28}$ & $2^{29}$ & 3 \\
\hline 10 & 12 & 22 \\
0 & $1^{30}$ & 1 \\
0 & $3^{31}$ & 3 \\
$9^{32}$ & $7^{33}$ & 16 \\
$9^{34}$ & $5^{35}$ & 14 \\
0 & $1^{36}$ & 1 \\
$16^{37}$ & 0 & 16 \\
0 & $1^{38}$ & 1 \\
$1^{39}$ & 0 & 1 \\
\hline 35 & 14 & 49
\end{tabular}

23. The unit of analysis in this table is Charter decisions. This inflates the number of federal and provincial statutes nullified since the same statute (or section of a statute) may be declared invalid in several different decisions. For example there were seven different Charter decisions that declared s. 8 of the Narcotic Control Act invalid. See Table 1. Also note that for the purposes of this table Noble and Stanger are each counted only once, although they appear twice in Table 1. Table 5 eliminates "double counting" and presents accurate figures for "charter casualties".

24. Big M Drug Mart v. The Queen (twice), supra, note 13.

25. R. v. Videoflicks; Zylberberg v. Sudbury Board of Education, supra, note 16.

26. R. v. Skinner; R. v. Keegstra; Canadian Newspaper Co. v. A. - G. Canada; Luscher v. Dep. Min. of Revenue Canada; Re Southam Inc. and the Queen; International Fund for Animal Welfare v. the Queen; Millar v. The Queen, supra, notes 13 and 16.

27. A. -G. Que. v. Chaussure Brown's; Rocket and Price v. Royal College of Dental Surgeons; Grier v. Alberta Optometric Association; Irwin Toyv. A. - G. Quebec; Edmonton Joumal v. A. - G. Alberta and A. -G. Canada; Singer v. A. -G. Quebec; Black and Co. v. Law Society of Alberna; Ford v. A. -G. Quebec, supra, notes 13 and 16.

28. Millar v. The Queen, supra, note 13 .

29. Black \& Co. v. Law Society of Alberta; Saskatchewan Dairy Workers Case, supra, note 16.

30. Reynolds v. A. -G. British Columbia, supra, note 16.

31. Skapinker v. Law Society of Upper Canada; Black \& Co. v. Law Society of Alberta; Basile v. A. -G. Nova Scotia, supra, note 16.

32. Re Metro News and The Queen; Vaillancourt v. The Queen; Giffv. The Queen; Martineau v. The Queen; Logan v. The Queen; Morgentaler v. The Queen; R. v. Bryant; S. Singh v. M.E.I.; R. v. Beare and Higgins, supra, note 13.

33. Ref. re B.C. Motor Vehicle Act (twice); R. v. Alston: R. v. Robson; R. v. Racette; R. v. Burr; Wilson v. Medical Services Commission of B.C., supra, note 16.

34. R. v. Rao; R. v. Noble; Hamill v. The Queen; R. v. LaPlante; Southam v. Hunter (twice); M.N.R. v. Kruger, Inc.; F.K. Clayton Group v. M.N.R.; A. -G. Canada v. Weatherall, supra, note 13.

35. R. v. Racette; R. v. MacAusland \& MacEwan; R. v. I.D.D.; R. v. Sheppard; R. v. Belliveau and Losier, supra, note 16.

36. Thwaites v. Psychiatric Facility, supra, note 16.

37. R. v. Cook; R. v. Carroll; R. v. Oakes (twice); R. v. Stanger; R. v. Stock; Re Pizzuro and Casemore; Vaillancourt v. The Queen; Giffv. The Queen; Martineau v. The Queen; R. v. Gough; R. v. Keegstra; $R$. v. L.D. Singh; $R$. v. Boyle; $R$. v. Driscoll; $R$. v. Ireco, supra, note 13.

38. Thibault v. Corporation des Medecins de Quebec, supra, note 16.

39. Smith v. The Queen, supra, note 13. 
[VOL. XXVIII, NO. 2

TABLE 2 (continued)

Charter Rights that served as basis for nullifying a statute

Category

of Rights

Equality Rights

Language Rights

Minority Education Rights

Aboriginal Rights

Legislative override

\section{Charter}

sections

15

$16-20$

23

25

33 equality rights

language rights

minority language education rights

aboriginal rights

notwithstanding clause

\begin{tabular}{ccc}
$\begin{array}{c}\text { Federal } \\
\text { statutes }\end{array}$ & $\begin{array}{c}\text { Provincial } \\
\text { statutes }\end{array}$ & $\begin{array}{c}\text { Total } \\
\text { cases }\end{array}$ \\
$3^{40}$ & $7^{41}$ & 10 \\
0 & 0 & 0 \\
0 & $3^{42}$ & 3 \\
0 & 0 & 0 \\
0 & $1^{43}$ & 1 \\
\hline 48 & 41 & 894
\end{tabular}

Sections 7 and 11(d) were the Charter rights responsible for the greatest number of nullifications with sixteen each. Section 7 protects the right to "life, liberty and security of the person, and the right not to be deprived thereof except in accordance with the principles of fundamental justice". Despite strong evidence of legislative intention to limit its meaning to matters of procedure, the Supreme Court has interpreted "principles of fundamental justice" to include substantive as well as procedural faimess. ${ }^{45}$ The Court has also interpreted section 7 to include more than security from arbitrary arrest or detention. ${ }^{46}$ The result has been to transform section 7 into an "omnibus right", capable of challenging diverse laws and policies of both levels of government.

The most celebrated section 7 case has been Morgentaler, ${ }^{47}$ striking down the abortion provisions of the Criminal Code. In a plurality decision, Chief Justice Dickson's and Justice Beetz's opinions stressed procedural defects contrary to the requirements of "the principles of fundamental justice". Justice Wilson found a substantive violation of a woman's "right to liberty". Despite the relative narrowness of the decision, Parliament has had difficulty enacting a revised abortion law. The Mulroney government's attempt to hold a "free vote" on a new abortion law resulted in a stalemate..$^{48}$ The practical effect of Morgentaler has thus been to eliminate all criminal restraints on access to abortion, although most provinces have continued to impose some restrictions on public funding and the licensing of private clinics.

40. Dywidag Systems Int'l Ldd. v. Zutphen Bros. Construction; Tetrault-Gadoury v. Canada Employment and Immigration Commission; Millar v. The Queen, supra, note 13.

41. Blainey v. Ont. Hockey Association; Connell v. U.B.C.; Stoffman v. Vancouver General Hospital; Gorzen v. Litz; Sniders v. A. - G. Nova Scotia; Colangelo v. Mississauga; Williams v. Haugen, supra, note 16.

42. Que. Assoc. of Prot. Schools v. A. -G. Quebec (twice); Reference re Education Act of Ontario, supra, note 16.

43. Alliance des Professeurs v. A. -G. Que., supra, note 16.

44. The discrepancy between 80 cases in Table 1 and 89 in this column is explained by the fact that there are five cases with two successful Charter claims, which are thus counted twice in Table 2: Keegstra, Vaillancourt, Giff, Martineau, Racette. There are two cases that have three successful Charter claims and are thus counted three times in Table 2: Millar, Black and Co.

45. Reference Re Section 94(2) of the Motor Vehicle Act (1985), 24 D.L.R. (4th) 536 (S.C.C.).

46. Operation Dismantle v. The Queen (1985) D.L.R. (4th) 481 at 518, per Wilson, J.

47. Morgentaler v. The Queen (1988), 44 D.L.R. (4th) 385 (S.C.C.).

48. For a fuller account, see Peter Russell, Rainer Knopff, and F.L. Morton, eds., Federalism and The Charter: Leading Constitutional Decisions (Carleton University Press, 1989), pp. 515-518. 
There have also been five section 7 decisions nullifying provisions of the Criminal Code because of insufficient legislative attention to the requirement of mens rea. ${ }^{49}$ Despite Justice Lamer's stated intention in the B.C. Motor Vehicle Reference ${ }^{50}$ to limit the substantive interpretation of section 7 to the field of criminal law and legal rights - what he termed "the traditional domain of the judiciary" - other courts have extended this doctrine to areas of economic and social policy. The British Columbia Court of Appeal struck down the province's attempt to remedy the shortage of doctors in nural areas. British Columbia's Medical Services Act restricted new health insurance billing numbers to doctors who agreed to practice medicine in rural areas of the province. The Court of Appeal ruled that this violated the doctors' liberty to pursue one's chosen occupation. ${ }^{51}$

In the Singh case, the Supreme Court interpreted section 7 as requiring that a person claiming refugee status must be given an opportunity to appear before the individual or body that makes the final determination of his status. ${ }^{52}$ The immediate effect of this decision was to seriously strain the resources of the Immigration Appeal Board. This resulted in a large backlog of refugee status claimants, and ultimately a new "stream-lined" Immigration Act. ${ }^{53}$ The Singh case has the potential to be extended to all administrative hearings that involve an adversary relationship between the government and a claimant.

The section 11(d) right to be presumed innocent has been used to strike down "reverse onus" provisions in the Criminal Code, the Narcotic Control Act, and the Food and Drugs Act. If Parliament is to resurrect the "reverse onus" procedure in criminal law, it will have to meet the section 1 "proportionality" test espoused by the Supreme Court in The Queen v. Oakes. ${ }^{54}$ The latter decision does not appear to completely prohibit the use of "reverse onus" procedures in criminal law, but it does mean that Parliament will have to convincingly spell out the "rational connection" between the "proven fact" and the "presumed fact".

The section 2(b) right to freedom of expression and press has accounted for the nullification of fifteen statutes, seven federal and eight provincial. The striking characteristic of these fifteen cases is that only two deal with political speech in the conventional sense: the Millar decision striking down restrictions on the political activities of civil servants and the Keegstra decision striking down the antiracial hatred section of the Criminal Code. Another case dealt with restrictions on public access to the seal hunt in Newfoundland.${ }^{5 s}$ The other twelve dealt, directly or indirectly, with speech related to commerce. There have been three cases in which newspaper companies have successfully challenged various restrictions on courtroom reporting ${ }^{56}$ and one case dealing with the importation of obscene

49. Vaillancourt v. The Queen (1987), 47 D.L.R. (4th) 399 (S.C.C.); R. v. Metro News (1986), 32 D.L.R. (4th) 321 (Ont. C.A.); $R$. v. Giff (1988), 42 C.C.C. (3d) 524 (Ont. C.A.); $R$. v. Martineau (1988), 43 C.C.C. (3d) 417 (Alta. C.A.); and R. v. Logan (1988), 67 O.R. (2nd) 87 (C.A.).

50. Reference Re Section 94(2) of the Motor Vehicle Act (1985), 24 D.L.R. (4th) 536 (S.C.C.).

51. Wilson v. Medical Services Commission of British Columbia (1988), 30 B.C.L.R. (2d) 1 (C.A.).

52. Re Singh and Minister of Employment \& Immigration (1985) 17 D.L.R. (4th) 422 (S.C.C.).

53. "Law expected to halve refugees", Globe and Mail, June 14, 1988.

54. [1986] 1 S.C.R. 103, 26 D.L.R. (4th) 200.

55. International Fund for Animal Welfare Inc. v. The Queen (1988), 45 C.C.C. (3rd) 457 (F.C.A.).

56. Canadian Newspapers Co. Ltd. v. A.G. Canada (1985), 16 D.L.R. (4th) 642 (Ont. C.A.); Re Southam Inc. and The Queen (1983), 146 D.L.R. (3d) 408 (Ont. C.A.); Re Edmonton Joumal and A. G. Alberta (1987), 41 D.L.R. (4th) 502 (Alta. C.A.) 
materials. ${ }^{57}$ There have been six decisions striking down restrictions on advertising: two involving professional associations' bans on commercial advertising ${ }^{; 8}$ one on television advertising targeted at children $; 9$ and three cases from Quebec dealing with legislation that restricted the use of English in advertising and business. ${ }^{60}$ The Nova Scotia Court of Appeal ruled that communication between a prostitute and her customers is protected speech, ${ }^{61}$ while the Alberta Court of Appeal ruled that restrictions on interprovincial law firms violated aspects of their freedom of expression. ${ }^{62}$

The section 8 right against unreasonable search or seizure has been the basis for fourteen nullifications. Section 8 has put an end to the use of writs of assistance ${ }^{63}$ and created a presumption of invalidity against all warrantless searches. ${ }^{64}$ In Hunter v. Southam Inc. ${ }^{65}$ the Supreme Court laid down strict new rules for the issuing of a valid search warrant. To be valid, a search warrant must be issued by a judge or someone "capable of acting judicially", that is, impartially. In particular it may not be issued by an administrator who also fulfills enforcement or investigatory functions. A valid search warrant can only be issued on grounds of "probable cause", and not "possible cause". Finally, it must specify the details of the search it authorizes: who is to do the searching, when, where, and for what. The Court has backed up these new rules with a strong proclivity to exclude evidence gathered in violation of them. ${ }^{66}$ In sum, section 8 has significantly tightened up the requirements for valid search and seizure practices.

The two other "fundamental freedoms" protected by section 2 have accounted for far fewer nullifications. The section 2(a) right to freedom of religion has served to strike down only three statutes. One case nullified a provision of the Ontario Education Act that allowed for a non-compulsory moment of prayer at the beginning of the school day. ${ }^{67}$ The others have dealt with Sunday closing, and their impact has been substantial. In one of its early Charter decisions, the Supreme Court ruled that the religious purpose of the federal Lord's Day Act violated the freedom of religion of non-Christians. ${ }^{68}$ The Supreme Court did allow that a Sundayclosing law with a secular purpose might be permissable, providing that its effects did not unduly infringe on the religious freedom of non-Christians.

57. Re Luscher and Deputy Minister, Revenue Canada (1985), 17 D.L.R. (4th) 503 (F.C.A.).

58. Re Rocket and Royal College of Dental Surgeons of Ontario (1988), 49 D.L.R. (4th) 641 (Ont. C.A.), and $R e$ Grier and Alberta Optometric Association (1987), 42 D.L.R. (4th) 327 (Alta. C.A.).

59. Irwin Toy v. A. G. Quebec (1986), 32 D.L.R. (4th) 641 (Que. C.A.).

60. A.G. Quebec v. La Chaussure Brown's Inc. (1986), 36 D.L.R. (4th) 374 (Que. C.A.); Ford v. A. G. Quebec (1988), 54 D.L.R. (4th) 577 (S.C.C.); Singer v. A. G. Quebec (1988), 55 D.L.R. (4th) 641 (S.C.C.).

61. R. v. Skinner (1987), 35 C.C.C. (3d) 203 (N.S. C.A.).

62. Black v. Law Society of Alberta (1986), 27 D.L.R. (4th) 527 (Alta. C.A.). This decision was affimed by the Supreme Court of Canada, April 20, 1989, although the main focus of the Supreme Court's decision was not s.2(b), but s.2(d).

63. Hamill v. The Queen (1987), 38 D.L.R. (4th) 611 (S.C.C.).

64. Simmons v. The Queen (8 Dec. 1988) (S.C.C.) [unreported].

65. Hunter v. Southam [1984] 2 S.C.R. 145, 11 D.L.R. (4th) 641.

66. Collins v. The Queen [1987] 1 S.C.R. 265.

67. Zylberberg v. Sudbury Board of Education (1988), 52 D.L.R. (4th) 577 (Ont. C.A.).

68. R. v. Big M Drug Mart Led. (1985), 18 D.L.R. (4th) 321 (S.C.C.) 
This decision set the stage for a challenge to the Sunday-closing provision of the Ontario Retail Business Holidays Act. The latter was initially declared invalid by the Ontario Court of Appeal, ${ }^{69}$ but subsequently upheld by a divided Supreme Court. ${ }^{70}$ The Court divided over whether or not, or the extent to which, a secular Sunday-closing law must provide exemptions for non-Christians. Despite the fact that its Sunday-closing law was upheld, Ontario subsequently amended it to allow municipalities to decide the issue on a local option basis. This is what Alberta had done three years earlier in response to the Lord's Day Act decision. In the more populous Edmonton-Calgary corridor, a domino-effect occurred, in which no municipality felt it could afford to force its merchants to close on Sunday while merchants in neighbouring towns were open for business. The practical effect of the new Alberta legislation has been to open up Sunday shopping in all but the more remote corners of the province. Critics of Ontario's new act fear a similar result there.

The section 2(d) right to freedom of association has been the basis for only three nullifications. The Federal Court of Appeal struck down the Public Service Employment Act's prohibition of "political work" by civil servants. ${ }^{71}$ The other section 2(d) cases both dealt with economic forms of association. Alberta's prohibition on out-of-province law firms was declared invalid by its own Court of Appeal. ${ }^{72}$ Saskatchewan's prohibition on strikes by workers in the province's dairy industry was also declared invalid, although this decision was subsequently reversed by the Supreme Court. ${ }^{3}$

The relatively small number of Court of Appeal decisions nullifying statutes on the basis of equality rights - $10-$ may be explained by the three year moratorium on section 15 litigation. Since section 15 came into force in April, 1985, there has been a veritable flood of equality rights litigation -386 reported cases by the end of 1988 - but few have reached the Courts of Appeal. While the success rate of the section 15 cases has been more or less the same as other Charter cases - 27\% - the equality rights cases have differed in one important respect. Two-thirds of the section 15 claims have challenged the validity of statutes. In other areas of Charter litigation, challenges to the conduct of state officials (usually the police) constitute two-thirds of the cases. ${ }^{74}$ This statute-oriented character of section 15 litigation suggests that it may fulfill Peter Hogg's description of it as "potentially the most intrusive" section of the Charter. ${ }^{75}$

What the section 15 nullifications lack in quantity they make up in scope and diversity. On the federal side of the ledger, section 15 has been successfully used to challenge restrictions on the political activities of civil servants, ${ }^{76}$ and the

69. R. v. Videoflicks Ld. (1984), 14 D.L.R. (4th) 10 (Ont. C.A.).

70. Edwards Books and Art Led. v. The Queen [1986] 2 S.C.R. 713.

71. Millar v. The Queen, (July 1988), (F.C.A.D.) [unreponted].

72. Black v. Law Society of Alberta (1986), 27 D.L.R. (4th) 527 (Alta. C.A.). Upheld by the Supreme Coust of Canada, April 20, 1989.

73. Re RWDSU and Govermment of Saskatchewan (1985), 19 D.L.R. (4th) 609 (Sask. C.A.).

74. The data on section 15 litigation is taken from F.L. Morton and Merril Cooper, "Litigating Equality Rights: A Statistical Analysis". Research Unit for Social Legal Studies, University of Calgary, Occasional Paper Series, 1989.

75. Peter Hogg, Canadian Constitutional Law, 2d ed., (Toronto: Carswell, 1985), p.797.

76. Millar v. The Queen, supra, note 71. 
denial of unemployment insurance benefits to persons over 65 years of age. ${ }^{n}$ Age discrimination claims have also accounted for three successful challenges to provincial mandatory retirement laws. ${ }^{78}$ This accurately reflects the trend in section 15 litigation generally, in which age has been the most litigated enumerated ground of discrimination..$^{79}$ The broad scope of section 15 is further illustrated by two successful challenges to Saskatchewan's Children of Unmarried Parents Act ${ }^{80}$ and the much publicized defeat of the "boys only" rule of the Ontario Hockey Association. ${ }^{81}$

Mobility rights (section 6) and minority language education rights (section 23) have both had some impact on provincial statutes. These two sections of the Charter are distinctive in that they were both intended to promote national unity by preventing the "balkanization of Canada" along economic (s.6) or linguistic (s.23) lines. ${ }^{82}$ Section 6 has been used to strike down restrictions on out-of-province businesses in Alberta ${ }^{83}$ and Nova Scotia. ${ }^{84}$ The Ontario Court of Appeal struck down the provincial Law Society's refusal to admit non-citizens, ${ }^{85}$ but this decision was subsequently reversed by the Supreme Court. ${ }^{86}$ More recently, however, the Supreme Court has struck down an almost identical British Columbia practice on section 15 discrimination grounds. ${ }^{87}$

Section 23 claims have been initiated in every province, all funded by the federal government's Court Challenges Programme. ${ }^{88}$ Only five of these cases had percolated up to the Appeal Court level by the end of 1988, three of which succeeded. In one of its most politically important Charter decisions to date, the Supreme Court (affirming the Quebec Court of Appeal) struck down the education provisions of Quebec's Bill 101, The Charter of the French Language. The latter severely restricted access to English-language education in Quebec, and clearly violated the intention behind the "Canada Clause" in section 23. ${ }^{89}$ The decision provoked

77. Re Tetreault-Gadoury and Canada Employment \& Immigration Commission (1988), 53 D.L.R. (4th) 384 (F.C.A.).

78. Harrison v. U.B.C. (1988), 49 D.L.R. (4th) 687 (B.C.C.A.), Stoffman v. Vancouver General Hospital (1988), 49 D.L.R. (4th) 727 (B.C.C.A.), and Sniders v. A.G. Nova Scotia (1988), 88 N.S.R. (2nd) 91 (C.A.).

79. Our research has disclosed the somewhat shocking fact that sixty percent of all section 15 litigation has been based on non-enumerated grounds; i.e. grounds other than race, national or ethnic origin, colour, religion, sex, age, or mental or physical disability. See Morton and Cooper, "Litigating Equality Rights".

80. Gorzen v. Litz (1988), 66 Sask. R. 211 (C.A.); Williams v. Haugen (13 Dec. 1988) (Sask. C.A.) [unreported].

81. Re Blainey and Ontario Hockey Association (1986), 26 D.L.R. (4th) 728 (Ont. C.A.).

82. Peter Hogg, "Federalism Fights the Charter of Rights", supra, note 5 at 1.

83. Black v. Law Society of Alberia (1986), 27 D.L.R. (4th) 527 (Alta. C.A.).

84. Basile v. A.G. Nova Scotia (1984), 11 D.L.R. (4th) 219 (N.S.C.A.).

85. Re Skapinker and Law Society of Upper Canada (1983), 3 C.C.C. (3d) 213 (Ont. C.A.).

86. Law Sociery of Upper Canada v. Skapinker [1984] I S.C.R. 357.

87. Law Society of B.C. v. Andrews, [1989] 1 S.C.R. 143.

88. See Angeline Martel, "Continuing the Vision and the Game: Mahe et al. v. Her Majesty the Queen, Alberta", Paper presented at the 1989 Annual Meeting of the Canadian Law and Society Association, Quebec City, June 3, 1980.

89. See Peter Hogg, The Charter of Rights Annotated, supra, note 5 at 60-64. 
deep resentment amongst Quebec nationalists, and contributed to the demand for the "distinct society" clause in the 1987 Meech Lake Accord.

In reply to a constitutional reference by the then Davis government, the Ontario Court of Appeal struck down the French-language provisions of the Ontario Education Act. Here it appears that the government actually wanted the old School Act declared invalid in order to generate constitutional legitimacy for its proposed extension of French-language education services. The government did not appeal its "loss".90

The language rights section of the Charter (ss.16-23) have also affected provincial rights indirectly by encouraging a new judicial boldness in language issues in general. Since the Charter was adopted in 1982, the Supreme Court of Canada has declared the entire statute books of two provinces - Manitoba' and Saskatchewan ${ }^{92}$ - to be invalid because they were not printed in both French and English. While the practical impact of the Saskatchewan decision was ultimately nil $^{93}$ and the effect of the Manitoba decision mitigated by the "rule of law" doctrine ${ }^{94}$ it is almost impossible to imagine the Court making either of these activist decisions twenty or even ten years ago. They are best explained by the new spirit of constitutional bilingualism inaugurated by the Charter. These activist decisions must be balanced against several other recent decisions where a majority of the Supreme Court exercised considerable self-restraint with respect to language rights. ${ }^{95}$ On balance, however, the judicial interpretation of language rights has tended to enhance the nation-building objectives of this section of the Charter by "making the whole of Canada a homeland for French-speaking as well as Englishspeaking Canadians", ${ }^{6}$ but only at the expense of provincial autonomy.

Table 2 clearly shows that different sections of the Charter are affecting the two levels of government differently. Legal rights account for $73 \%(35 / 48)$ of the successful Charter challenges to federal statutes, but only $34 \%(14 / 41)$ of the successful challenges to provincial statutes. This contrast reflects the federal government's constitutional jurisdiction over criminal law. Conversely, Charter claims based on the non-legal rights constitute a much higher percentage of successful challenges to provincial statutes - 66\% (27/41) - than to federal statutes $-27 \%(13 / 48)$. As noted above, the impact of the mobility rights and minority language education rights sections have been exclusively on provincial law-making.

90. For details, see F.L. Morton, "The Political Impact of the Canadian Charter of Rights and Freedoms", (1987) 20 Canadian Joumal of Political Science 31 at 49.

91. Reference Re Manitoba Language Rights [1985] S.C.R. 347.

92. Mercure v. A.G. Saskatchewan (25 Feb. 1988) (S.C.C.) [unreported].

93. The Mercure decision rested on an interpretation of section 110 of the Northwest Territories Act of 1886. This was a statute, not a constitutional document, and was thus subject to legislative revision. The Saskatchewan government of Premier Grant Devine promptly introduced legislation repealing the section, thus negating the practical effect of the Supreme Court's decision.

94. Having declared all of the Manitoba Statutes invalid, the Supreme Court appealed to the "rule of law" to avoid legal chaos. The Court invoked the "de facto" doctrine to sustain the temporary validity of Manitoba's statutes for an interim transition period to fully bilingual statutes.

95. In Sociésé des Acadiens v. Association of Parents, [1987] I S.C.R. 549, Justice Beetz (for the majority) distinguished legal rights ("rooted in principle") from language rights ("founded on political compromise") and argued "the courts should pause before they decide to act as instruments of change with respect to language rights". A similar self-restraint was evident in Bilodeau v. Anorney General of Manitoba, [1986] 1 S.C.R. 449, and MacDonald v. Ciry of Montreal, [1986] 1 S.C.R. 460.

96. Peter Hogg, "Federalism Fights the Charter of Rights", supra, note 5 at 1. 


\section{IMPACT ON PROVINCIAL STATUTES}

As noted above, the impact of the Charter on federal and provincial statutes, while numerically equal, has not been identical. Different sections of the Charter are affecting the two levels of government differently. This difference is further elaborated by the data presented in Table 3. The last two columns of Table 3 show that while the actual number of federal and provincial statutes declared invalid by appeal courts is almost identical (32 and 31), the total number of Charter challenges to federal statutes -256 - has been more than double the number of provincial statutes challenged -119 . This means that appeal courts have declared $26 \%$ of the provincial statutes challenged before them to be invalid, but only $12.5 \%$ of the federal statutes. The "nullification rate" for provincial statutes is thus double that for federal statutes.

TABLE 3

Substantive versus Procedural Nullifications Procedural

Substantive

Total

Total no. statute cases

Federal Statutes Nullified Provincial Statutes Nullified

Totals

28

14

42

6

$18 \quad 31^{98}$

256

24

63

375

Table 3 also shows that $88 \%$ ( 28 of 32 ) of the nullifications of federal statutes have involved procedural provisions, while $58 \%$ (18 of 31 ) of the nullifications of provincial statutes have involved substantive provisions. This difference is significant in terms of measuring the qualitative (as opposed to quantitative) impact of the Charter.

The substantive-procedural distinction refers to the difference between "what" a government is permitted to do under the Charter and "how" it does it. Procedural provisions are instrumental, aimed at defining how enforcement or prosecution under an act is to be carried out. They are not, in other words, indicative of the main objects of the legislation. While their nullification may frustrate enforcement of government policy, it usually does not directly block or pre-empt the enforcement of the legislation. A government is free to amend and "fine tune" the invalid procedure(s) in accordance with the judicial ruling and then to re-enact the legislation.

Most of the Charter decisions nullifying federal statutes discussed above (Table 2) are examples of procedural nullifications. The courts have not ruled that Parliament cannot use reverse onus provisions in the Criminal Code, but only that they must meet the "rational connection" test. Similarly, the courts have not used section 8 to prohibit police searches, but have only required that they be authorized ahead of time by appropriately issued warrants. Immigration officials have not been told that they must grant all requests for refugee status, but only that they must offer the claimants an opportunity to present their case in person.

97. Morgentaler and Keegstra are counted as both procedural and substantive, but only once in the row total.

98. Wilson is counted as both procedural and substantive, but only once in the row total. 
Nullification of substantive parts of legislation usually presents a more direct and more serious challenge to parliamentary democracy and the principle of "responsible government" which it embodies. Nullification of substantive statutory provisions tells a government, and the electoral majority that elected it, that it cannot enforce the policies it desires. In the short term, it leaves the government concerned with the stark options of abandoning the policy at stake or invoking the section 33 legislative override.$^{99}$ It thus heightens the legislative-judicial tension inherent in a system of constitutionally entrenched rights such as the one Canada adopted in 1982.

The most obvious examples of substantive nullifications and the kind of judiciallegislative confrontations they can provoke have been the Bill 101 cases from Quebec. Both the education provisions ${ }^{100}$ and the public signs sections ${ }^{101}$ of Bill 101 have been struck down by the courts. Both decisions were vehemently denounced within Quebec as unwarranted attacks on Quebec's right to govern itself in these matters. The intended effect of the Chaussure Brown decision was subsequently negated by Premier Bourassa's use of the section 33 legislative override.

A similar confrontation occurred in Saskatchewan in 1985. The Dairy Workers (Maintenance of Operations) Act ${ }^{102}$ was passed by the Saskatchewan legislature in 1984 to end a work stoppage by striking dairy workers. In June of 1985 the Saskatchewan Court of Appeal held that the "back to work" legislation was contrary to the freedom of association protected by s.2(d) of the Charter. ${ }^{103}$ This ruling resulted in the Saskatchewan government invoking the s.33 override provisions of the Charter when adopting similar legislation in a later labour dispute. ${ }^{104}$ This turned out to be unnecessary, as the Supreme Court subsequently reversed the Court of Appeal decision. ${ }^{105}$

It should be noted that the concepts of substantive and procedural nullifications represent "ideal types" at opposing ends of a theoretical spectrum. In actual practice, it is not always clear whether a statute has been nullified on substantive or procedural grounds. For example, the "constructive murder" provision struck down in Vaillancourt ${ }^{106}$ can be plausibly interpreted as either substantive or procedural. We chose to treat it and related federal cases ${ }^{107}$ as procedural because

99. A possible third option may be to pursue the same policy objectives through less restrictive means. This appears to have been the message that the Supreme Court tried to send to the Quebec government in its Ford and Devine decisions. While theoretically possible, in practice a government may think that its policy objective is inseparable from the means chosen to pursue it. Premier Bourassa's decision to ignore the Court's invitation and use the section 33 override suggests that he saw the means (a total prohibition on English-language public signs) as inseparable from the end (preservation of Quebec's "French face"). The longer term options include pursuing a constitutional amendment or waiting for the Court to overtum the precedent at a later date. The latter is usually dependant on personnel changes on the Court, aided and abetted by a political use of the appointment process.

100. Quebec Association of Protestant School Boards v. A. G. Quebec [1984] 2 S.C.R. 145, 10 D.L.R. (4th) 321.

101. Ford v. A.G. Quebec (1988), 54 D.L.R. (4th) 577 (S.C.C.).

102. S.S. 1983-84, c.D-1.1.

103. Re RWDSU and Government of Saskatchewan (1985), 19 D.L.R. (4th) 609 (Sask. C.A.).

104. See F.L. Morton, "The Impact of the Charter of Rights", supra, note 90 at 46-47.

105. Saskatchewan v. RWDSU [1987] I S.C.R. 460.

106. (1987) 47 D.L.R. (4th) 399 (S.C.R.).

107. Supra, note 15. 
the Charter infraction is based on the reduced burden on the Crown to prove mens rea in murder cases - a procedural issue. Of course, it can be argued that this reduced burden of proof is the very essence of constructive murder, and should be treated as a substantive nullification. On balance, we found this interpretation plausible but less persuasive. It should be noted that we were consistent in also classifying as procedural provincial statutes nullified on similar mens rea grounds. ${ }^{108}$

The ambiguity between procedural and substantive nullification has also been reflected in Charter jurisprudence. In Reference Re B.C. Motor Vehicle Act the Supreme Court struck down British Columbia's attempt to make driving with a suspended license an "absolute liability" offense. In his obiter dicta for a unanimous Court, Justice Lamer emphatically rejected limiting the meaning of section 7 to procedural issues. Yet after embracing a substantive interpretation of section 7 , Justice Lamer then proceeded to strike down the impugned statute for procedural reasons. ${ }^{109}$

In Morgentaler ${ }^{110}$ the Supreme Court recognized the importance of the procedure-substance distinction, but disagreed on how to treat it. Four of the five Justices in the majority explicitly limited their ruling of invalidity to the procedural requirements of the abortion law, leaving Parliament wide scope to deal with abortion. Justice Wilson, by contrast, intentionally chose to deal with the substantive issue of whether the "right to liberty" includes a woman's right to terminate a pregnancy without any government interference. She argued that the Court "must tackle the primary issue first", because it would be "purely academic" to canvass the procedural requirements "if such requirements cannot...be imposed at all."'II Her ruling - had it been endorsed by a majority - would have significantly reduced the government's options in trying to frame a new abortion policy. To complicate matters further, despite the fact that he begins by disavowing any substantive review, Chief Justice Dickson seems to come very close to adopting it. ${ }^{12}$ In sum, the substantive-procedural distinction is easier to make in theory than in practice.

Keeping this caveat in mind, it is still significant that 18 out of the 24 substantive nullifications under the Charter have involved provincial laws. These have included the voiding of the Canadian citizenship requirement for lawyers in Andrews, ${ }^{113}$ the nullification of the disenfranchisement of convicted prisoners in several provincial election acts, ${ }^{114}$ and the striking down of mandatory retirement laws for university professors and doctors, ${ }^{115}$ to name several. This trend suggests that there has been greater conflict between the Charter and provincial legislation

108. Reference Re Section 94(2) of the B. C. Motor Vehicle Act (1985), 24 D.L.R. (4th) 536 (S.C.C.); $R$. v. Burt (1987), 38 C.C.C. (3d) 299 (Sask. C.A.); and R. v. Alston (1985), 22 C.C.C. (3d) 563 (B.C.C.A.).

109. (1985), 24 D.L.R. (4th) 536.

110. (1988), 44 D.L.R. (4th) 385 (S.C.C.).

111. Ibid. at 483 .

112. The Chief Justice speaks of security of the person as including a right to "bodily integrity" and a right against "serious state-imposed psychological stress" especially when the law in question requires a woman to meet "criteria unrelated to her own priorities and aspirations".

113. Law Society of B.C. v. Andrews, supra, note 87.

114. Re Reynolds and A.G. B.C. (1984), 11 D.L.R. (4th) 380 (B.C.C.A.); Badger v. A.G. Manitoba (12 March 1986) [unreported].

115. Harrison v. U.B.C. (1988), 49 D.L.R. (4th) 687 (B.C.C.A.) and Stoffman v. Vancouver General Hospital (1988), 49 D.L.R. (4th) 727 (B.C.C.A.). 
than is initially indicated in Tables 1 and 2 . The data in Table 3 supports the predictions that the Charter would have a greater effect on policy areas under provincial jurisdiction than federal. ${ }^{116}$

A further difference in the impact of the Charter on federal and provincial statutes can also be discerned by comparing the dates of enactment of the statutes nullified. If the statutes affected by the Charter have been on the books for decades, reflecting archaic or outdated public opinion, the "anti-democratic" critique of judicial nullification would be weakened. It can be argued that these statutes were ripe for reform, and the fact that reform came at the hands of judges rather than a law reform commission would not seem to matter. The Supreme Court's decision striking down the Lord's Day Act comes to mind. ${ }^{117}$ This eighty year old statute could hardly be said to represent the policy consensus of Parliament or contemporary Canadian society, and the Court's decision provoked little criticism.

The same could not be said of statutes that have been recently enacted and represent important policy initiatives of current governing parties. In cases such as these, the "anti-democratic" character of judicial review is more pronounced, since the statutes involved represent the policy choice of contemporary governments and the political majorities that elected them. The Supreme Court's decision in the two Bill 101 cases $^{118}$ are examples of this kind of case.

\begin{tabular}{lccc}
\multicolumn{3}{c}{ TABLE 4 } \\
Enacted & Nullified Statutes Grouped by & $\begin{array}{c}\text { Dates of Enactment } \\
\text { Statutes Nullified }\end{array}$ \\
& & Provincial & Total \\
Pre-1960 & Federal & 4 & 18 \\
$1960-69$ & 14 & 1 & 8 \\
$1970-79$ & 7 & 14 & 22 \\
$1980-88$ & 8 & 12 & 15 \\
Total & 3 & 31 & $63^{\prime \prime 9}$
\end{tabular}

The data presented in Table 4 indicate that nullified provincial statutes are of a much more recent "vintage" than their federal counterparts. Of the latter, $66 \%$ were enacted before 1970 . By contrast, $84 \%$ of the nullified provincial statutes have been enacted since 1970. Alternately, the mean date of enactment for the nullified federal statutes is 1952 , but 1970 for provincial statutes. Two of the federal statutes were veritable dinosaurs, the Lord's Day Act and the obscenity provisions of the Customs Tariff Act, enacted in 1906 and 1907, respectively. By contrast, ten of the nullified provincial statutes were enacted since 1980, while only three federal statutes fall into this category. Three of the provincial statutes - the two Bill 101 cases from Quebec and Saskatchewan's "back-to-work" legislation - were major

116. This was the hope of many Charter champions and the fear of many Charter opponents during 1980-81. See Knopff and Morton, "Nation Building and the Charter", supra, note 4 at 133-182.

117. R. v. Big M Drug Mart Lid. (1985), 18 D.L.R. (4th) 321 [S.C.C.].

118. Quebec Association of Protestant School Boards v. A. G. Quebec (1984), 10 D.L.R. (4th) 321 (S.C.C.); and Ford v. A.G. Quebec (1988), 54 D.L.R. (4th) 577 (S.C.C.).

119. The difference between 63 nullified statutes, as opposed to a figure of 80 in Tables 1 and 7 , is explained by the fact that 5 court of appeal decisions were overtumed by the Supreme Court of Canada, and 15 cases were "shadow cases", where one statute was overtumed in a number of different cases. Here, the unit of analysis is the number of statutes, or parts thereof, which were struck down for being contrary to the Charter, and not the number of cases in which a statute, or part thereof, was declared invalid. 
policy initiatives of the government of the day. These three cases can be seen as prototypes of the kind of judicial-legislative conflicts that can arise under the Charter.

Table 5 breaks down the impact of the Charter by province. It shows that British Columbia's statutes have been most affected with seven nullifications. Ontario, Saskatchewan and Quebec follow with five each. This may be a good example of the inability of objective data to accurately represent political reality, since it is obvious that Quebec has felt the most aggrieved by Charter decisions to date.

\begin{tabular}{|c|c|c|c|}
\hline \multicolumn{4}{|c|}{$\begin{array}{l}\text { TABLE } 5 \\
\text { Statutes Nullified Under Charter by Legislative Jurisdiction }\end{array}$} \\
\hline & $\begin{array}{l}\text { statutes w/ } \\
\text { procedural provision }\end{array}$ & $\begin{array}{c}\text { statutes } w / \\
\text { substantive provision }\end{array}$ & $\begin{array}{c}\text { Total no. of } \\
\text { statutes nullified }\end{array}$ \\
\hline Govemment of Canada & 28 & 6 & 32120 \\
\hline British Columbia & 4 & 4 & 7121 \\
\hline $\begin{array}{l}\text { Alberta } \\
\text { la }\end{array}$ & 0 & 3 & 3 \\
\hline Saskatchewan & 4 & 1 & 5122 \\
\hline Manitoba & 1 & 0 & 1 \\
\hline Ontario & 0 & 5 & $5^{123}$ \\
\hline Quebec & 2 & 3 & 5124 \\
\hline New Brunswick & 1 & 0 & 1 \\
\hline Nova Scotia & 0 & 2 & 2 \\
\hline PEI & 1 & 0 & 1 \\
\hline Newfoundland & 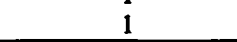 & 0 & 1 \\
\hline Totals & 42 & 24 & 63125 \\
\hline
\end{tabular}

\section{ARE JUDGES BECOMING MORE ACTIVIST?}

Within the academic legal community, it has been recognized from the start that the impact of the Charter would be more a function of judicial behaviour than the actual "letter of the law". Just as most constitutional commentators "blamed" the Supreme Court's self-restraint for the "ineffectiveness" of the 1960 Canadian Bill of Rights, so they hoped that a new judicial activism would breathe vigor and life

120. Morgentaler and Keegstra are counted as both substantive and procedural for purposes of columns 1 and 2, but only count once each in the row total. Also note that there are four cases nullifying federal statutes that are counted only once although two subsections or two related sections were nullified by the decision. These four cases are Southam v. Hunter, Clayton, S. Singh, and Keegstra. Dywidag nullified two different statutes and both are counted here. The Saskatchewan Court of Appeal decision in Beare and Higgins is not counted, as it was reversed on appeal by the Supreme Court of Canada.

121. Wilson is counted as both substance and procedure for purposes of columns 1 and 2 , but only counts once in the row total.

122. There have been six Appeal Court decisions nullifying Saskatchewan statutes, but one - the Dairy Workers Case - was reversed by the Supreme Court of Canada on appeal and thus is not counted here.

123. Two Ontario Court of Appeal decisions that nullified provincial statutes were overtumed by the Supreme Court of Canada on appeal - Skapinker, and Videoflicks by Edwards Books - and so are not counted here.

124. One Quebec Court of Appeal decision that nullified a provincial statute was overturned by the Supreme Court of Canada on appeal - A.G. Quebec v. Inwin Toy.

125. The reader should note that the difference between this figure -63 - and the figure of 80 in Tables 1 and 7 is explained by the five Appeal Court decisions overtumed by the Supreme Court of Canada (See supra, note 119); and 15 "shadow cases", i.e. cases which nullify the same statute. For example, there are seven cases that nullify s.8 of the Narcotics Control Act. In Table 1, where the unit of analysis is the case, they are each counted separately, but here where the unit of analysis is the statute, they are all counted as only one. 
into the Charter. ${ }^{126}$ The Supreme Court did not disappoint its academic critics in its early Charter decisions. In its first fifteen Charter decisions - between 1984 and early 1986 - the Court ruled in support of the Charter claimant in nine of fifteen cases - a remarkable $60 \%$ "success rate". Over the next two years, however, the Court upheld Charter claims in only eight of thirty-two Charter cases. Russell cites this "modest" success rate of only $25 \%$ as evidence that the Supreme Court was "applying the brakes to the Charter express". ${ }^{127}$

TABLE 6

\begin{tabular}{lcccc}
$\begin{array}{l}\text { Year of } \\
\text { Decision }\end{array}$ & $\begin{array}{c}\text { Prov'l } \\
\text { statutes }\end{array}$ & $\begin{array}{c}\text { Fed'l } \\
\text { statutes }\end{array}$ & $\begin{array}{c}\text { Total Statutes } \\
\text { declared invalid }\end{array}$ & $\begin{array}{c}\text { Total No. } \\
\text { statute cases }\end{array}$ \\
1982 & 0 & 0 & 0 & 2 \\
1983 & 1 & 3 & 4 & 46 \\
1984 & 4 & 3 & 7 & 50 \\
1985 & 5 & 5 & 10 & 48 \\
1986 & 3 & 2 & 5 & 71 \\
1987 & 4 & 9 & 13 & 72 \\
1988 & 14 & 10 & 24 & 86 \\
\hline Totals & 31 & 32 & $63^{128}$ & 375
\end{tabular}

While Russell's account is accurate vis-à-vis the Supreme Court's Charter jurisprudence, it fails to capture the larger impact of the Charter. Table 6 shows that when the scope of analysis is expanded to include all Court of Appeal decisions, the evidence suggests that the impact of the Charter is increasing not abating. Only in 1986 was the number of nullifications less than the year before. $1988-$ the year that began with Morgentaler and ended with Chaussure Brown - set a new record high of 24 nullifications, almost double the previous high set in 1987. The number of statutes being challenged under the Charter has also increased, from about 50 appeal court decisions per year for the first three years to almost 80 per year since 1986. (See Table 6) But this $60 \%$ increase in Charter challenges cannot by itself account for the $150 \%$ increase in invalidated statutes during the same period. The steady increase in the number of statutes being nullified under the Charter is portrayed by Figure 1.

126. See F.L. Morton and R. Knopff, "Continuity and Change in a Written Constitution: A Critical Analysis of the Living Tree Doctrine". Forthcoming in Supreme Court Review 1988.

127. Russell, "Canada's Charter of Rights and Freedoms: A Political Report", pp. 390-91.

128. The unit of analysis in this table is "statutes". Thus, the five court of appeal decisions reversed by the Supreme Court are not counted. Similarly, multiple nullifications of the same statute (or section of a statute) count as only one nullification, e.g. s.8 of the Narcotic Control Act. 
FIGURE 1

Nullified Statutes by Year of Decision

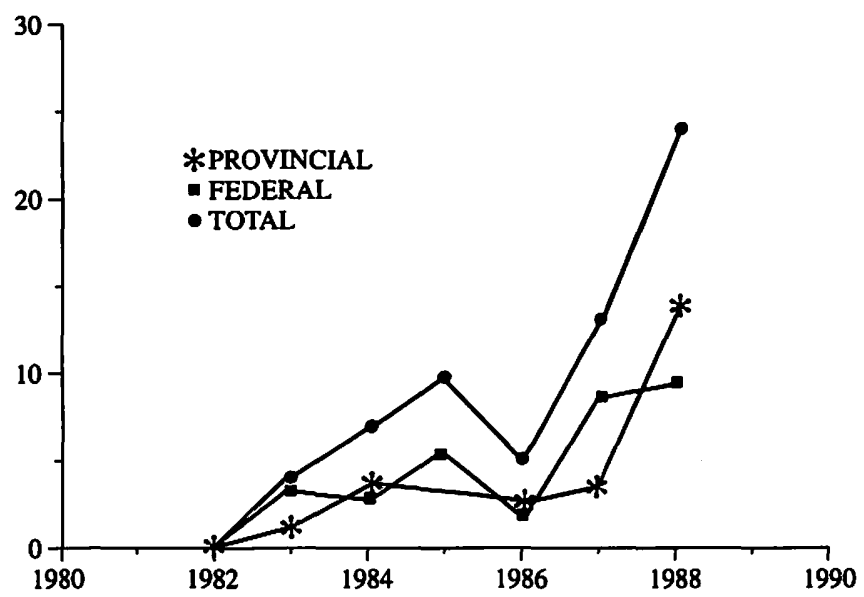

The most plausible explanation for this trend is the influence of the Supreme Court's activist Charter jurisprudence on provincial Appeal Court judges. An earlier study found that provincial Courts of Appeal were the least activist of all levels of courts in dealing with Charter claims. ${ }^{129}$ This was not surprising considering that they were guided mainly by pre-Charter precedents and especially the very selfrestrained jurisprudence of the 1960 Canadian Bill of Rights. The Supreme Court, both in what it has written and what it has done, has now explicitly rejected the authority of this jurisprudence as a guide to Charter interpretation. As Table 7 indicates, the Supreme Court has established a new norm of judicial activism when dealing with the Charter. Both the force of stare decisis and the more informal leadership role of Canada's highest court have pulled lower courts in the same direction.

While Charter activism is increasing generally, judicial enthusiasm for this new role is not evenly shared among the twelve Appeal Courts included in the study. As indicated in Table 7, the Ontario Court of Appeal has been the most activist court in absolute terms with 20 nullifications in 105 cases. In relative terms, where the cases are numerous enough to show a statistically significant trend, the Supreme Court of Canada has been the most activist, striking down 34\% (13 of 38) of the statutes challenged in the Charter cases it has decided. The mean nullification rate for all Courts of Appeal was 22\%. The Manitoba Court of Appeal has been the least receptive to Charter challenges to statutes, striking down only one statute in $\mathbf{2 5}$ cases, a scant $4 \%$. The British Columbia Court of Appeal had the next lowest nullification rate, $14 \%$.

129. Morton and Withey, "Charting the Charter, 1982-1985", supra, note 6 at 84. 
TABLE 7

\begin{tabular}{lccc} 
Court of Appeal & $\begin{array}{c}\text { No. of Statutes Nullified by the } \\
\text { No. of Decisions } \\
\text { Nullifying Statutes }\end{array}$ & $\begin{array}{c}\text { Courts of Appeal } \\
\text { \% of Statute } \\
\text { Cases Decided }\end{array}$ & $\begin{array}{c}\text { No. of Statute } \\
\text { Cases Decided }\end{array}$ \\
Supreme Court & 13130 & $34 \%$ & 38 \\
Federal Court & 7 & $27 \%$ & 26 \\
British Columbia & 8 & $14 \%$ & 57 \\
Alberta & 10 & $29 \%$ & 35 \\
Saskatchewan & 8 & $28 \%$ & 29 \\
Manitoba & 1 & $4 \%$ & 25 \\
Ontario & 20 & $19 \%$ & 105 \\
Quebec & 4 & $36 \%$ & 11 \\
New Bnunswick & 1 & $50 \%$ & 2 \\
Nova Scotia & 5 & $18 \%$ & 28 \\
Prince Edward Island & 2 & $67 \%$ & 3 \\
Newfoundland & 1 & $14 \%$ & 7 \\
\hline Total & 80 & $22 \%$ & 366
\end{tabular}

The Charter jurisprudence of the Supreme Court of Canada is also reflected in its handling of Charter appeals involving statutes from lower Courts of Appeal, to the extent that this might be statistically significant. The Supreme Court has affirmed the lower Appeal Court rulings in $66 \%$ (25 of 38) of these appeals. In seven of these cases the statute was struck down by both courts, and in eighteen cases upheld by both courts. The Supreme Court has reversed lower Appeal Court decisions in $29 \%$ ( 11 of 38 ) of these cases, five times to uphold a statute and six times to nullify. In other words, when the Supreme Court has affirmed a lower court ruling, it has usually ( $72 \%$ ) done so to uphold the statute; but when it has reversed, it has usually (55\%) done so to strike down the statute.

It remains to be seen whether the trend toward increased judicial nullification of statutes will continue. There may be a lag between the Supreme Court's post-1986 "moderation" and lower Appeal Court behaviour. By this account, the number of nullifications should level off as the lower Appeal Courts fall in step with the Supreme Court's less activist Charter jurisprudence. ${ }^{131}$ On the other hand, once the traditional, pre-Charter judicial ethos of self-restraint and deference to elected legislatures has been weakened, if not discredited, the most effective brake on the nullification of statutes is gone. The sheer quantity of Charter litigation also complicates effective leadership from the top court. As noted earlier, less than two percent of all court of appeal decisions are reviewed by the Supreme Court. These considerations suggest that it may be quite difficult to "brake the Charter express"'.

\section{FEDERALISM AND THE CHARTER}

While the Charter has had a disproportionately greater impact on provincial statutes, it would be a mistake to conclude that Canadian judges are mounting a Charter-inspired assault on provincial rights. There are numerous examples of judicial support for provincial statutes in the face of Charter challenges. The

130. This includes Hamill, a challenge to the "writs of assistance" clause of s.10(1)(a) of the Narcotic Control Act, which the Crown conceded violated s.8.

131. This explanation was offered by Peter Russell. 
Supreme Court of Canada, for example, has upheld several important pieces of provincial legislation against Charter attacks: Alberta's and Saskatchewan's antistrike legislation; ${ }^{132}$ Ontario's Sunday closing law; ${ }^{133}$ and Ontario's new policy to extend full public funding to Roman Catholic high schools. ${ }^{134}$

The disproportionate impact of the Charter on provincial law-making is not simply a function of changing judicial attitudes and behaviour. It reflects a deeper structural conflict between federalism and the Charter, and the two different conceptions of minority rights that they entail. The logic of federalism conceives of Canada as a collection of regional minorities, whose rights are protected by granting local government for local issues. This equation of provincial rights with minority rights is most pronounced in the case of Quebec, but applies to the other provinces as well. ${ }^{135}$ Any incursion on provincial rights is seen as an attack on minority rights.

The concept of minority rights embedded in the Charter collides with the logic of federalism. Under the Charter, the relevant minorities are defined by ethnic, racial, linguistic, religious, and sexual characteristics. The Charter's purpose is to protect these minority groups and their individual members from hostile or intolerant government policies - including provincial policies. The Charter thus confers constitutional priority to certain rights and interests of groups within each province over and against the right of the province to be self-governing within its traditional sphere of jurisdiction. The Charter superimposes a new set of constitutional restraints on policy areas formerly under the exclusive jurisdiction of the provinces. Where federalism allowed and even encouraged diverse provincial policies, the Charter potentially imposes uniform national standards.

The theoretical tension between federalism and the Charter is actualized by the different sociological composition of local and national communities. Local and provincial governments generally serve more homogeneous communities, and are more likely to reflect their constituents' opinions and habits in their laws. The more homogeneous the community, the more likely that it will seek to have its "way of life" embodied in the local laws, and the less tolerant it is of individuals and minority groups who do not share its "way". Quebec, again, is the clearest case of this, but it is true to a lesser degree of the other provinces, especially the less urban, less populated ones. By contrast, the national government is responsible to a much more diverse population, and its laws must accommodate this diversity. As a result, national policies are likely to be more moderate, tolerant and "middleof-the-road"'. The Charter largely incorporates these national norms, and thus is likely to conflict with local and provincial policies.

Finally, the method of administering the Charter further enhances its centralizing tendencies. Primary responsibility for enforcing the Charter is vested with the judiciary, one of the most centralized institutions of Canadian government. Unlike the dual court system characteristic of most federal states, the Supreme Court of

132. Reference Re Public Service Employee Relations Act (Alta.) [1987] 1 S.C.R. 313; Saskatchewan v. Retail, Wholesale and Dept. Store Union [1986] 1 S.C.R. 460.

133. Edwards Books and Arts Lid. v. The Queen [1986] 2 S.C.R. 713.

134. Réference Re Bill 30, An Act to Amend the Education Act [1987] 1 S.C.R. 1148.

135. This issue is developed further in F.L. Morton, "Group Rights versus Individual Rights in the Charter: The Special Cases of Natives and the Quebecois", in Neil Nevitte and Allan Komberg, eds. Minorities and the Canadian State (Toronto: Mosaic Press, 1985), pp. 71-85. 
Canada has jurisdiction and final say over provincial as well as federal laws. The federal government also controls judicial appointments to the provincial superior courts. The vesting of this appointment power with the federal government was intended to ensure a uniform and impartial administration of federal laws in the provincial courts. It also promotes a national perspective amongst superior court judges. The final and authoritative superintendence of the Supreme Court, combined with the doctrine of stare decisis, ensures that the Charter will receive a relatively uniform interpretation and development. The not uncommon American spectacle of recalcitrant state supreme courts refusing to comply with Supreme Court decisions is highly improbable in Canada. If there is any provincial resistance to the Supreme Court's Charter decisions, it will have to come from the provincial legislatures not the courts.

This tension between the Charter and federalism, minority rights and provincial rights, is mediated by several factors. Judges can lessen the tension by interpreting the Section 1 "reasonable limitations" clause of the Charter in a manner that respects provincial diversity. ${ }^{136}$ The Supreme Court's initial interpretations of Section 1 - Quebec Protestant School Board ${ }^{137}$ and Oakes ${ }^{138}$ - "left little room for the introduction of federal values into the concept of reasonable limitations". ${ }^{139}$ In the more recent Edwards Books, ${ }^{140}$ however, most members of the Court seem to have abandoned the "least drastic means" test of Oakes in favour of the more accommodating test of "as little as is reasonably possible". With the exception of Justice Wilson, the Court seemed willing to allow room for the different provinces to work out different solutions to the problem of exemptions from secular Sunday-closing laws. In the area of criminal law enforcement, the Court recently ruled that administrative variations by the provinces do not necessarily violate the section 15 equality requirements. ${ }^{141}$ If this kind of judicial respect for provincial diversity becomes central to Section 1 "reasonable limitations" jurisprudence, the centralizing influence of the Charter would be moderated.

A non-judicial check on the centralizing influence of the Charter is the Section 33 legislative override clause. Section 33 allows a provincial government to reenact a nullified statute or to newly enact a statute, with the proviso that it shall operate "notwithstanding" the Charter of Rights. Peter Hogg has called this the "most important protection for federal values in the Charter of Rights". ${ }^{142}$ Thus far Section 33 has been used sparingly outside of Quebec. Saskatchewan used it in a pre-emptive fashion to protect its back-to-work legislation for striking workers

136. What follows is a brief summary of Peter Hogg's treatment of this issue in, "Federalism Fights The Charter of Rights", supra, note 5 at 9-21.

137. [1984] 2 S.C.R. 66.

138. [1986] 1 S.C.R. 103.

139. Hogg, "Federalism Fights The Charter", supra, note 5 at 16

140. R. v. Edwards Books and Art [1986] 2 S.C.R. 713.

141. $R$ v. Turpin, Supreme Court of Canada (unreported), May 9, 1989. Justice Wilson wrote the opinion for a unanimous court, and was careful to circumscribe her ruling: "I would not wish to suggest that a person's province of residence or place of trial could not in some circumstances be a personal characteristic of the individual or group capable of constituting a ground of discrimination. I simply say it is not so here."

142. Hogg, "Federalism Fights The Charter", supra, note 5 at 5. 
in the province's dairy industry. ${ }^{143}$ Quebec is the one government to make extensive use of Section 33. After the Charter was adopted in 1982 over the protests of then Premier Rene Levesque, the Parti Quebecois government enacted a "blanket" override statute that purported to apply the notwithstanding clause to all existing Quebec legislation. ${ }^{144}$ The P.Q. government also began to routinely insert a Section 33 notwithstanding clause into all new Quebec statutes. This practice was eventually discontinued in March, 1986 by the Liberal government of Robert Bourassa, which replaced Levesque and the P.Q. in the elections of December, 1985. Both of these practices were largely symbolic protests against Quebec's "exclusion" from the Constitutional Accord of November, 1981, and not attempts to abridge civil rights and liberties within Quebec. If the intent was to abridge civil rights and liberties within Quebec, surely the Quebec government would have also applied a blanket override clause to the Quebec Charter of Rights and Freedoms.

This changed in December, 1988, when the Bourassa government used Section 33 to avoid compliance with the Supreme Court's decision in Chaussure Brown ${ }^{145}$ Despite the resignation of his three anglophone Cabinet ministers and strong condemnations from outside Quebec, Bourassa declared that the practical effect of the Supreme Court's decision - the posting of English-language signs and advertising - was unacceptable to Quebec. Bourassa's actions are likely to make it easier for other provincial premiers to invoke Section 33 in the future to defend what they consider matters of vital public policy from Charter nullification. If so, Section 33 could become in practice what it is in theory, "the ultimate shield for provincial diversity." 146

If the Meech Lake Accord is eventually adopted, it too could effect the centralizing tendency of the Charter. The "distinct society" clause is clearly intended by its supporters to influence judges' perception of what constitutes a "reasonable limitation" of Charter rights in the case of Quebec statutes. Quebec nationalists believe that with the "distinct society" clause in the Constitution, some of the Bill 101 cases that they have lost would be decided differently. Restrictions on English language education and advertising, for example, could be defended as reasonable attempts by Quebec "to preserve and to promote" its distinctively French heritage. ${ }^{147}$

Finally, the Meech Lake Accord proposes to confer on the provinces the function of nominating candidates for appointment to the Supreme Court of Canada. The Accord also guarantees that at least three of the Justices come from Quebec, and would thus have to be nominated by the Quebec government. These proposals would give the provinces a direct hand in shaping the composition of the Supreme Court. In theory this new power of nomination could allow provinces - and especially Quebec - to indirectly restrict the centralizing tendency of Charter

143. This incident is discussed in Morton, “The Political Impact of the Charter", supra, note 90 at $46-47$ and Hogg, "Federalism Fights The Charter", supra, note 5 at 6-7.

144. An Act Respecting the Constitution Act, 1982; S.Q. 1982, c.21.

145. A.G. Quebec v. La Chaussure Brown's Inc. (1986), 36 D.L.R. (4th) 374 (Que. C.A.); Ford v. A. G. Quebec (1988), 54 D.L.R. (4th) 577 (S.C.C.); Singer v. A.G. Quebec (1988), 55 D.L.R. (4th) 641 (S.C.C.).

146. Hogg, "Federalism Fights The Charter", supra, note 5 at 8.

147. Ibid., pp. 21-23. 
jurisprudence by nominating judges sympathetic to the values of federalism and provincial rights.

To date, judicial appointments in Canada have remained free of the ideological strife that has engulfed the U.S. Supreme Court. Legal expertise and character, not theories of constitutional interpretation and ideological orientation, have continued to be the decisive criteria for appointments to the Supreme Court of Canada. This could, of course, change as the Charter increasingly pushes judges to the centre stage of Canadian politics. Judicial decisions such as the spate of contradictory abortion decisions beginning with Morgentaler will make Canadians become more sophisticated about the extent of judicial discretion and the influence of a judge's personal values in Charter interpretation. As the perception grows that it is the Charter interpreters and not the Charter makers who decisively shape the meaning of the Charter, the appointment process - including the nominating stage is likely to become more politicized. Pressure will grow to appoint the "right kind" (or "left-kind") of judge. Under the Meech Lake Accord, provincial governments would become key players in the new sport of judicial politics, somewhat analogous to the role of the U.S. Senate in appointments to the American Supreme Court.

\section{CONCLUSION}

Assessing the impact of the Charter is a much more complex task than simply counting the number of statutes invalidated by the courts. The quantitative approach used in this study necessarily treats all cases equally, when in reality all cases are not equal. The Colangelo decision, which struck six words from a subsection of the Ontario Municipal Act, is hardly on a par with the Ford and Devine cases decisions that triggered a chain of events which now threaten national unity. With this caveat in mind, however, statistical studies can make an important - we would argue necessary - contribution to the larger and more complex task of determining how the Charter is affecting Canadian government and politics. They provide a starting point - grounded in real facts - from which other studies can start and build, qualify and elaborate. Statistical studies also provide a healthy empirical check on other interpretations of the Charter's impact.

This study confirms and documents that the Charter has served as a catalyst for a new and - for Canada - an unprecedented style of judicial activism. ${ }^{148}$ By expanding its scope beyond the Supreme Court to include all Courts of Appeal, this study discloses that a substantially larger number of statutes have been invalidated under the Charter than had been previously reported. The study also suggests that the Charter has had a qualitatively different and marginally greater impact on provincial statutes than federal statutes. This difference reflects a deeper tension between federalism and the Charter. The tension between provincial rights and minority rights can be either moderated or exacerbated by different modes of

148. Those who try to deny this usually use the American Supreme Court during the "Warren Court" era (1953-1968) as their point of comparison. The relevant comparison is to the Canadian judiciary's handling of the 1960 Bill of Rights. From 1960 to 1982, there were only five Bill of Rights cases won by the individual in the Supreme Court of Canada. In only one of these - Drybones v. The Queen, [1970] S.C.R. 282 - was a statute declared invalid. As Table 7 indicates, in just six years under the Charter the Supreme Court has already nullified 13 statutes. For a more detailed discussion, see Morton, "The Political Impact of the Charter', supra, note 90 at 34-36. 
judicial interpretation of the Section 1 " reasonable limitations" clause. Provinces can directly shield themselves from the centralizing effect of the Charter through the use of the Section 33 legislative override, and indirectly through the judicial appointment process if the Meech Lake Accord is adopted. ${ }^{149}$ The advent of the Charter is clearly challenging the traditional politics and patterns of Canadian federalism. While the Charter is unlikely ever to replace federalism as the central organizing principle of Canadian politics, it is certainly changing it. How much and in what directions remains to be seen. 